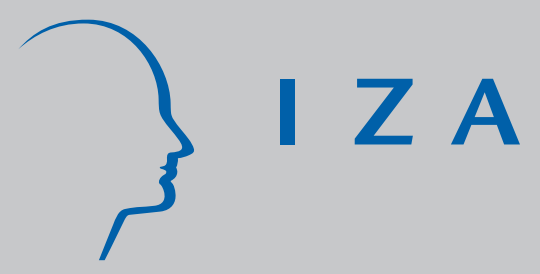

IZA DP No. 496

\title{
Changes in the Structure of Earnings During the
} Polish Transition

Michael P. Keane

Eswar S. Prasad

May 2002 


\title{
Changes in the Structure of Earnings During the Polish Transition
}

\author{
Michael P. Keane \\ Yale University \\ Eswar S. Prasad \\ International Monetary Fund \\ and IZA Bonn
}

Discussion Paper No. 496
May 2002

IZA

P.O. Box 7240

D-53072 Bonn

Germany

Tel.: +49-228-3894-0

Fax: +49-228-3894-210

Email: iza@iza.org

This Discussion Paper is issued within the framework of IZA's research area Labor Markets in Transition Countries. Any opinions expressed here are those of the author(s) and not those of the institute. Research disseminated by IZA may include views on policy, but the institute itself takes no institutional policy positions.

The Institute for the Study of Labor (IZA) in Bonn is a local and virtual international research center and a place of communication between science, politics and business. IZA is an independent, nonprofit limited liability company (Gesellschaft mit beschränkter Haftung) supported by the Deutsche Post AG. The center is associated with the University of Bonn and offers a stimulating research environment through its research networks, research support, and visitors and doctoral programs. IZA engages in (i) original and internationally competitive research in all fields of labor economics, (ii) development of policy concepts, and (iii) dissemination of research results and concepts to the interested public. The current research program deals with (1) mobility and flexibility of labor, (2) internationalization of labor markets, (3) welfare state and labor markets, (4) labor markets in transition countries, (5) the future of labor, (6) evaluation of labor market policies and projects and (7) general labor economics.

IZA Discussion Papers often represent preliminary work and are circulated to encourage discussion. Citation of such a paper should account for its provisional character. A revised version may be available on the IZA website (www.iza.org) or directly from the author. 


\title{
ABSTRACT \\ Changes in the Structure of Earnings During the Polish Transition*
}

We document changes in the structure of earnings during the economic transition in Poland. We find that inequality in labor earnings increased substantially from 1988 to 1996. A common view is that the reallocation of workers from a public sector with a compressed wage distribution, to a private sector with much higher wage inequality, accounts for the bulk of increased earnings inequality during transition. However, our decomposition of the sources of the increase in inequality suggests that this compositional effect accounts for only $39 \%$ of the increase. Fully $52 \%$ of the increase is due to the increase in the variance of wages within sectors. That is, earnings inequality within both the private and public sectors grew substantially, and by similar amounts. This illustrates how even state-owned enterprises in Poland moved towards competitive wage setting as they restructured.

A substantial part of the increase in earnings inequality was between group, due largely to increased education premia. However, changes in inequality within education-experiencegender groups account for about 60 percent of the increase in overall wage inequality--similar to the patterns observed in the U.S. and U.K. in the 1980s. But, in contrast to the U.S. and U.K. experiences, increases in within-group inequality in Poland were very different across skill groups, with much larger increases for highly educated workers. These patterns hold in both the private and public sectors, although increases in education premia were somewhat greater in the private sector.

JEL Classification: J31, O33, P20

Keywords: $\quad$ wage inequality, between and within-group inequality, education and experience premia, labor reallocation, transition

\author{
Eswar S. Prasad \\ Research Department \\ International Monetary Fund \\ 700 19th Street, N.W. \\ Washington, DC 20431 \\ USA \\ Tel.: (202) 623-8493 \\ Fax: (202) 589-8493 \\ Email: eprasad@imf.org
}

\footnotetext{
"We thank the staff at the Polish Central Statistical Office, especially Wieslaw Lagodzinski and Jan Kordos, for assistance with the data and Krzysztof Przybylowski and Barbara Kaminska for translations of the survey instruments. We received helpful comments from Elizabeth Brainerd, Susan Collins, Oded Galor, Stephen Machin, numerous other colleagues, and seminar participants at the IMF, the North East Universities Development Conference, and meetings of the Econometric Society, the Society for Economic Dynamics, and the American Economic Association. Research funding was provided by the National Council for Eurasian and East European Research. The views expressed in this paper are those of the authors and do not necessarily represent those of the IMF.
} 


\section{Introduction}

Poland experienced a dramatic change in its political and economic structures during the last decade. This transition from a communist to a market economy was launched with a radical set of reforms in late 1989 and early 1990 that has become known as the "big bang." The communist government ended food price controls as it left power in August 1989, and the new Mazowiecki government implemented the Balcerowicz plan in January 1990, ending price controls on most other products. Other aspects of the reforms included reductions in state orders for manufactured goods and the imposition of hard budget constraints on state owned enterprises (SOEs). The hardening of budget constraints arose both through elimination of direct state subsidies and the reform of the National Bank in late 1991. ${ }^{1}$

The pace of privatization of SOEs in Poland has been rather slow compared to a number of other Eastern European countries. For instance, Pinto, Belka, and Krajewski (1993) report that, out of a sample of 75 of the 500 largest firms in Poland, only 3 had been privatized by June 1992 (two and one-half years into the transition). ${ }^{2}$ However, the private sector's contribution to GDP rose sharply during the transition (from $29 \%$ in 1989 to $60 \%$ in 1995) due largely to an explosion of small-scale entrepreneurship. In addition, there is strong evidence that hard budget constraints and import competition resulted in rapid adjustment by SOEs to the new market environment. Pinto et al (1993) provide a good discussion of the nature of these adjustments, which included massive labor shedding, changes in product lines and marketing strategies, and attempts to improve efficiency through investment. ${ }^{3}$

\footnotetext{
${ }^{1}$ Commander and Dhar (1998) report subsidies fell from 13\% of GDP in 1989 to 2\% in 1994.

224 of the 75 SOEs had been "commercialized." Essentially, this means that control was transferred from a workers' council that could hire and fire managers, to a supervisory board that contains four members from the Ministry of Privatization and two members chosen by employees. But ownership remained with the Treasury. This was viewed as an intermediate step that would allow the firm to be restructured prior to privatization.

3 A strong case can be made that a slow pace of privatization was desirable. For instance, Pinto et al report that nearly all the managers they interviewed considered restructuring prior to privatization as essential because "potential investors do not want to talk to workers' councils or deal with firms burdened with social assets, excess employment, and unmarketable products." They argue that managers of SOEs had two incentives to restructure: 1) so that they would be retained in the future (after privatization), and 2) the expectation that they would get cheap shares once privatization occurred. The notion that privatization per se would not lead to restructuring, but rather that the nature of managerial incentives and financial constraints are critical, is emphasized by Frydman and Rapaczynski (1994).
} 
The transition process has also involved significant changes in labor market institutions. For instance, constraints on layoffs and redundancies have been significantly eroded over time. The unemployment rate rose from essentially zero in 1988 to a peak of $16.4 \%$ in 1994 . Furthermore, there has been a massive inter-sectoral reallocation of labor. ${ }^{4}$ The rapid rise of the private sector-which is far less unionized than the public sector and much less subject to regulations in terms of wage setting - has also resulted in greater labor market "flexibility" in many dimensions. And very generous pensions led massive numbers of older workers to take early retirement during the early phase of the transition.

After a sharp contraction of output in 1990-91, Poland has experienced sustained economic growth, which became quite rapid in the mid-90s. As Keane and Prasad (2002) discuss, Poland has been the greatest success story of the transition process. By 1999, its GDP stood at 22\% above its pre-transition (1988) level, while even the best performing of the remaining transition countries had only managed to recover to within a few points plus or minus their pre-transition levels. At the same time, Poland experienced only a very modest increase in income inequality. Given its relative success, it is particularly important to document what happened during the transition process in Poland.

In this paper, we document changes in the structure of labor earnings in Poland over the period 1985-1996. Our analysis is based on micro data from the Polish Household Budget Surveys (HBS). The relatively long span of the dataset allows us to trace out changes in the structure of earnings for an extended period of time - both leading up to and following the "big bang." We find that overall earnings inequality rose significantly during the transition period of 1989-1996. For instance, we estimate that the $\log 90 / 10$ percentile ratio for individual labor earnings (of employed workers) increased steadily from 0.97 in 1988 to 1.12 in 1996 (using a sample of individuals aged 18-60 for whom labor earnings is the primary source of income), a $16 \%$ increase in the $90 / 10$ ratio $(\exp (0.15))$. For male workers, the increase was slightly

\footnotetext{
${ }^{4}$ Coricelli, Hagemejer and Rybinski (1995) report that employment was 17.7 million in 1988. Of this, 9.6 million were in the public sector, 4.1 million were in private agriculture, 2.7 million were in worker cooperatives, and 1.3 million were in the nonagricultural private sector. By 1992, these figures were 6.6, 4.1, 1.1 and 3.8 million, respectively, along with 2.5 million unemployed. Thus, 2.5 million private sector jobs were created in just four years. Note that the labor force increased to 18.1 million, largely due to an inflow of women.
} 
greater, with the $\log 90 / 10$ ratio rising from 0.94 in 1988 to 1.15 in 1996 , a $23 \%$ increase.

To put this increase in earnings inequality in perspective, Juhn, Murphy and Pierce (1993) report an increase in the log 90/10 ratio for wages of male U.S. workers from 1.27 in 1979 to 1.48 in 1989 , a $23 \%$ increase in the 1980 s. Thus, by this measure, the increase in earnings inequality in Poland from 1988 to 1996, was very similar to that for the U.S. in the 1980s. Of course, our measure of the increase in earnings inequality in Poland, based only on employed workers, understates the actual increase, because it ignores the effect of the 16 percentage point increase in unemployment. ${ }^{5}$

We also conduct a detailed examination of the sources of the increase in earnings inequality. Prior to the transition, the wage structure in Poland was highly compacted, with wages of college-educated white-collar workers little different from those of manual workers. A common view is that the rise of the private sector, in which there is competitive wage setting and, hence, a more unequal wage distribution, is the main source of increasing earnings inequality during transition. But our results contradict this view. In Poland, earnings inequality is indeed higher in the private sector (e.g., the log 90/10 earnings ratio in 1996 was 1.19 in the private sector and 1.05 in the public sector), and the private sector share of (non-agricultural) employment did increase from $5 \%$ in 1988 to $39 \%$ in $1996 .{ }^{6}$ Still, we find that reallocation of labor from the public to the private sector accounted for only $39 \%$ of the total increase in earnings inequality (as measured by the change in variance of log earnings).

The majority of the increase in earnings inequality during the Polish transition (52\%) was due to increased variance of wages within both the public and private sectors. That is, earnings inequality within both the private and public sectors grew substantially, and by similar amounts. ${ }^{7}$ This illustrates how even state-owned enterprises in Poland have engaged in substantial restructuring, as suggested by Pinto et al (1993) and others. Consistent with our

\footnotetext{
${ }^{5}$ In Keane and Prasad (2002) we show that inequality in labor earnings of worker-headed households increased sharply in the transition, but that generous government transfers kept this from translating into substantial increases in overall income inequality.

${ }^{6}$ These are the figures from our HBS micro data.

${ }^{7}$ Exactly how similar is sensitive to the inequality measure chosen, but this in itself suggests it is not obvious that the increase in inequality was much greater in the private sector.
} 
findings, Commander and Dhar (1998) report (p. 127) a substantial increase in the heterogeneity of wages across SOEs between 1990 and 1994, with those that performed better in terms of sales offering higher wages. ${ }^{8}$

The transition also involved substantial shifts in the industry composition of employment. The share of employment in manufacturing dropped from $37.2 \%$ in 1988 to $30.6 \%$ in 1996, while shares of various service industries grew. But this inter-industry labor reallocation had a negligible impact on earnings inequality. A within vs. between industry decomposition indicates that $97 \%$ of the increase in earnings inequality is within industry.

Our estimates of standard human capital earnings functions indicate that education premia rose rapidly during the transition. But the premium for labor market experience declined in the early years of transition and the position of older workers deteriorated relative to younger workers, consistent with rapid obsolescence of industry- and firm-specific skills. These patterns are even stronger in the private sector than in the aggregate economy.

We find that a substantial fraction of the increase in overall earnings inequality is attributable to changes in within-group inequality. A striking result is that increases in withingroup inequality are concentrated among workers with higher levels of formal education. ${ }^{9}$

It does not appear that existing models of transition can fully capture the changes in the structure of earnings that we observe for Poland. For instance, Aghion and Commander (1999) and Commander and Tolstopiatenko (1998) consider a model with a state sector and a private sector. In the state sector, firms operate under a zero-profit constraint with no capital accumulation (insiders extract all of the surplus) and wages are set equal to average product. Private sector firms behave competitively. The state sector is less efficient (as captured by a lower constant in the Cobb-Douglas production function). State firms face a probability of

\footnotetext{
8 Since our data contains information on the ownership of a worker's firm, but not the identity of firms, we can't distinguish the extent to which the increased variability of wages in the public sector is within vs. between SOEs.

9 These patterns are rather different from the patterns documented for the U.S. and the U.K. in the 1970s and 1980s. In those countries, both education and experience premia increased, and inequality within all education and experience categories increased as well, particularly during the 1980s (see, e.g., Juhn, Murphy and Pierce, 1993, for evidence from the U.S.; Machin, 1996, and Machin and Van Reenen, 1998, for the U.K.). In fact, Gould, Moav and Weinberg (2001) present some evidence that, in the 1970s and 1980s, growth in within-group inequality in the U.S. may have been lower for workers with higher levels of formal education.
} 
closure, and can choose to restructure, in which case they shed excess labor and become like private firms. There is unemployment if hiring by private firms falls short of exits from state firms. Inequality within each sector is set exogenously in the model, and the authors assume a higher level in the private sector. When this model is simulated, higher inequality arises during the transition for two main reasons: 1) workers shift from the relatively low inequality state sector to the higher inequality private sector, and 2) mean wages are higher in the private sector (due to its greater productivity). The latter feature leads to a Kuznets curve (i.e., an inverse U-shape for inequality) because, with a mean wage differential between the two sectors, the contribution of between sector inequality to total inequality peaks when the allocation of workers between the two sectors is equal.

As our analysis reveals, this type of model misses several key features of the data. First, mean wage differences between sectors are not an important factor driving changes in inequality (and, furthermore, mean wages are actually lower in the private sector than in the public sector). Second, inequality has grown within both sectors over time, and this is the main factor driving changes in inequality. Third, inequality has not followed a Kuznets curve but has trended upward until reaching a plateau. Fourth, the model does not account for the greater increase of inequality among the more educated, which also happens to be the group that has had the least reallocation into the private sector.

The model could be modified to explain rising inequality of earnings in the state sector over time if it accounted for restructuring of SOEs in the absence of privatization - the phenomenon that Pinto et al (1993), Commander and Dhar (1998) and others suggest is important. Clearly, as the fraction of firms engaged in competitive wage setting grows (both through increases in the size of the private sector and restructuring of SOEs), the relative demand for skilled labor will increase in the economy as a whole. Through this mechanism, inequality will also grow in the private sector during the transition. ${ }^{10}$

Assuming the state sector has moved closer to competitive wage setting, another source

\footnotetext{
${ }^{10}$ Of course, another mechanism driving increased inequality within the state sector may simply be the need to compete for labor with the growing private sector. Increased labor mobility across sectors, industries and firms would naturally be expected to raise within-group inequality as search gives rise to an equilibrium wage distribution.
} 
of increasing inequality within that sector may have been price liberalization and opening to trade. For example, energy prices were held artificially low prior to 1990 , and oil could be imported cheaply from the USSR. As Keane and Prasad (1996) note, there is a large body of empirical work suggesting that energy is complementary with unskilled labor and substitutable with both capital and skilled labor in manufacturing production. Thus, an increase in the price of energy would increase the demand for skilled labor relative to the unskilled labor. This is the same mechanism whereby a falling price of capital increases skill premia in Krusell, Ohanian, Rios-Rull and Violante (2000).

In addition, the transition can be interpreted as a period of technical change, not in the sense that the technical frontier has shifted out, but rather in the sense that SOEs have reorganized to achieve greater technical efficiency, and modified production processes to reflect market prices of inputs (in particular, by eliminating labor hoarding). Much of the existing capital was presumably rendered obsolete. There are a number of models where more educated workers are better able to adapt to rapid changes in production processes (see, e.g., Acemoglu, 1998; Caselli, 1999), and this mechanism may help explain rising returns to skill.

A rapid pace of change may also help explain rising within-group inequality. For instance, Violante (2002) proposes a model in which technology is embodied in capital of different vintages. Given frictions in the matching of workers with new technology, an acceleration of the rate of technical progress (i.e., updating of capital) leads to increased wage dispersion among identical workers. Growth in within-group inequality can then be explained by frictions in the matching of workers with the new technology. Clearly, however, this framework needs to be modified to account for the fact that increases in within-group inequality in Poland are positively correlated with education level. ${ }^{11}$

In the next section of the paper we review prior work on the distribution of earnings in

\footnotetext{
11 In Galor and Moav (2000), rising returns to education increase within-group inequality among the highly educated through a compositional effect. They model human capital as being a function of innate ability as well as formal education. In their model, technological progress that increases the returns to education without affecting the return to innate ability leads some lower-ability individuals to invest in education, thereby widening the ability dispersion (and, hence, the dispersion of wages) among educated workers. At the same time, dispersion is narrowed among the less educated. Our data do indicate an increase in the fraction of the population getting a college degree in Poland over the 1988-1996 period. But whether this mechanism can have a quantitatively important impact on within-group inequality over such a short period is unclear.
} 
Poland. In section III we describe the HBS data that we use in our analysis. Section IV contains our analysis of changes in earnings inequality, and section $\mathrm{V}$ contains our estimates of human capital earning functions and an analysis of changes in the structure of earnings during the transition. Section 6 concludes.

\section{Prior Research on Earnings Distributions in Poland and Other Transition Countries}

Most earlier work on the Polish earnings distribution has relied on aggregate statistics that are released annually by the Polish Central Statistical Office (CSO). These aggregate statistics are described in detail in Atkinson and Micklewright (1992). Each September, starting in 1981, the CSO conducted a census of enterprises, and "the information requested of the enterprise was the total persons in a number of discrete earnings bands." The CSO then published aggregate statistics such as total numbers of employees in various earnings bands, and deciles of the earnings distribution. From this data, it is possible to construct approximate measures of earnings inequality, such as approximate Gini coefficients. A number of other countries, such as Hungary, the former Czechoslovakia, and the former U.S.S.R., had similar data collection and reporting procedures for earnings.

Using such data, Atkinson and Micklewright (1992) compare the degree of earnings inequality across several communist countries in 1986. They obtain Gini values for Czechoslovakia (1987), Hungary, Poland and the U.S.S.R. of 0.197, 0.221, 0.242 and 0.276, respectively. And they report 90/10 decile ratios of 2.45, 2.64, 2.77 and 3.28, respectively. ${ }^{12}$ Thus, there was a clear ranking of inequality (consistent across both measures), with Czechoslovakia being the most equal, the U.S.S.R. the least equal, and Poland in the middle. As a point of comparison, these authors report a Gini coefficient and 90/10 decile ratio of 0.267 and 3.23, respectively, for the U.K. in 1986. Thus, the earnings distribution in Poland prior to the transition was noticeably more compact than in the U.K. Based on the same data, Atkinson and Micklewright (1992) also calculate that earnings inequality in Poland declined over the period 1986-89. They report Gini values of $0.242,0.230,0.212$ and 0.207 for these years, and decile ratios of 2.77, 2.76, 2.60 and 2.43 .

\footnotetext{
${ }^{12}$ Based on the average earnings of individuals in the top and bottom deciles of the distribution.
} 
Rutkowski (1996a) uses the same September earnings distribution survey to examine changes in the Polish earnings distribution during the transition. His calculations indicate that earnings inequality jumped dramatically in the early phase of the transition, with the Gini and decile ratio rising to 0.242 and 2.86, respectively, in 1991. By 1993, the last year of his study, these had risen further, to 0.257 and 3.03. Rutkowski also reports that earnings inequality was much greater in the private sector than in the public sector in 1993, that the ratio of white collar to blue collar wages rose substantially in the transition, and that this ratio was much higher in the private sector. Rutkowski (1998) extends this analysis to 1995, by which time the Gini for earnings increased to 0.288 and the decile ratio to 3.38 , a large increase in inequality over 1993. Recall that, for 1986, Atkinson and Micklewright (1992) reported a Gini of 0.242 and a decile ratio of 2.77. So the increase in (gross) earnings inequality for Poland from 198695 implied by these data is somewhat greater than what they report for the U.K. in the 1980 s. ${ }^{13}$

Rutkowski (1996b) presents a cross-country analysis of changes in earnings inequality using similar data sources for several transition economies. These results indicate that, by 1993, the earnings distribution for Czechoslovakia had become very similar to that for Poland, while the Gini and decile ratio for Hungary had risen to 0.315 and 3.67 (more unequal than Poland). Thus, given the baseline figures from Atkinson and Micklewright (1992), it appears that both Czechoslovakia and Hungary experienced larger increases in earnings inequality from 1986 to 1993 than did Poland. Newell (2001) reports similar results.

As both Atkinson and Micklewright (1992) and Rutkowski (1996) describe, there are a number of limitations of the September earnings survey data for Poland. First, the aggregate nature of the data may lead to approximation errors in inequality measures, and limits the type of analysis that can be performed. Second, the coverage of establishments is incomplete because small firms (i.e., less than 6 employees) are not sampled. This is especially a problem for the transition in Poland because, according to OECD (1998, p. 107), "Poland's recent growth performance rests on a strong entrepreneurial basis, with many dynamic small and

\footnotetext{
${ }^{13}$ Note that, for both Poland and the U.K., the data are gross earnings. Atkinson and Micklewright (1992, Table BE1) report that the 90/10 ratio for earnings in Britain increased from 2.96 in 1979 to 3.39 in 1989, a 15\% increase. For men alone, however, they report an increase from 2.38 to 3.08 over the same period $(+29 \%)$.
} 
medium-sized enterprises (SMEs) and creations of new firms ... SMEs make up the bulk of Poland's 2.2 million registered non-agricultural enterprises ... almost 90 percent [are] microenterprises (employing 1 to 5 persons)." Third, this data does not account for in-kind payments, which have been important in Poland. Fourth, this survey reports gross earnings. This creates comparability problems over time, because a progressive income tax (with rates up to 45 percent) was introduced in 1992. Failure to account for this will tend to exaggerate the measured increase in inequality of net earnings.

Another survey that has been used by some authors to examine recent changes in the Polish wage structure is the Polish Labor Force Survey that was introduced in 1992 (see, e.g., Newell and Socha, 1998). However, this survey is clearly not useful for understanding changes in wage inequality in the crucial early years of transition or changes relative to the pretransition wage structure.

Existing work on other transition economies has focused mostly on the early years of transition (a recent exception is Newell, 2001). For instance, Orazem and Vodopivec (1995) analyze micro data from Slovenia and report that, from 1987 to 1991, wage inequality increased markedly, with returns to both education and experience rising over this period. Using grouped data, Flanagan (1993) finds that the returns to education rose while the returns to experience declined in the Czech Republic in the initial phase of transition. Brainerd (1998) reports that, from 1991 to 1994, the return to a year of education almost doubled for workers in Russia. Garner and Terrell (1998) find that wage dispersion in the Czech and Slovak Republics increased in the early years of transition. Using data from the ILO, Freeman and Oostendorp (2000) have created the new Occupational Wages around the World file and, using this dataset, find that overall earnings inequality and skill differentials increased in transition economies during the 1980s and 1990s. 


\section{The Household Budget Survey}

The CSO has been collecting detailed micro data on household income and consumption at least since 1978, using fairly sophisticated sampling techniques. The Household Budget Survey (HBS) attempts to obtain a random sample of Polish households. ${ }^{14}$ The typical sample size is about 25,000 households per year. The CSO uses HBS data to create aggregate tabulations that are then presented in their annual Statistical Bulletins, or Surveys.

The HBS contains detailed information on sources and amounts of income both for households and individuals within each household. Total income is broken down into four main categories: labor income (including wages, salaries and nonwage compensation); pensions; social benefits and other transfers; and other income. A key point is that the labor income data include measures of the value of in-kind payments from employers to workers, which have been an important part of workers' compensation in Poland and other transition economies. There were no taxes on personal income until $1992 .{ }^{15}$ After that year, we use net incomes in the analysis.

The HBS also contains information on demographic characteristics of all household members and on labor earnings of all employed individuals in each household. Unfortunately, data on individual workers' earnings were not collected in 1993. Hence, the dataset we use in this paper in fact goes from 1985-92 and then from 1994-96.

The HBS includes a limited panel element - a part of the dataset contains households that are surveyed for four successive years before being rotated out of the sample. However, the panel was changed completely a couple of times over the period 1985-96. In our analysis, we treat the data as a set of repeated cross-sections.

The structure of the survey instrument and the sampling scheme were both kept essentially unchanged throughout the transition period. However, one major change was

\footnotetext{
14 A two-stage geographically stratified sampling scheme is used, where the first-stage sampling units are area survey units and the second-stage units are individual households within the area. Due to differential response rates across different household types and regions, the CSO constructs sampling weights to achieve a representative sample. We report results using these weights, but our results were not sensitive to whether or not the weights are employed.

${ }^{15}$ Until 1992, some firms were subject to an "excess wage tax," essentially a payroll tax imposed on part of a firm's total wage bill. The actual incidence of this tax is, of course, a complicated matter.
} 
introduced in 1993 that has important implications for analyzing cross-sectional inequality. In 1993, the CSO switched from quarterly to monthly data collection. Since earnings are more variable at the monthly than the quarterly frequency, this shift alone would have created a substantial increase in measures of cross-sectional earnings inequality. Indeed, as we demonstrate in the next section, failure to account for this change in survey frequency has quantitatively important effects on measures of earnings inequality.

In the Appendix, we develop a technique for adjusting the 1994-1996 earnings data for the increased variability that may be attributable to the shift from quarterly to monthly reporting. Our approach models earnings as the sum of a permanent or predictable component (determined by workers' education, age and other observable characteristics) and a mean zero idiosyncratic component. We then assume that the variance of the idiosyncratic component would not have jumped abruptly after the $4^{\text {th }}$ quarter of $1992 .{ }^{16}$ Rather, we assume that the variance of idiosyncratic earnings varied smoothly over time (measured in months) according to a polynomial time trend. We estimate this polynomial trend, along with a dummy for the post-1992 period that captures the discrete jump in variance that occurred with the change to monthly earnings reporting. Then, at the individual level, we scale down the idiosyncratic component of the post-1992 earnings statistics to eliminate this jump in variance.

Our procedure for adjusting for the spurious increase in inequality stemming from the switch to the monthly reporting interval relies on access to the HBS micro data. In particular, the variance correction requires access to the data for an extended period of time. Our study is unique in that it is based on the HBS micro data for a long sample period extending from 4 years prior to the "big bang" to 7 years after. To our knowledge, no prior study of earnings inequality in Poland has adjusted for the change in survey design in $1993 .^{17}$

\footnotetext{
${ }^{16}$ This is a reasonable assumption, because we are unaware of any major policy changes or external shocks that occurred at this point.

${ }^{17}$ At the time we began our study, the Polish CSO had never before released the HBS micro data. Subsequently, the micro data for the first half of 1993 was released to the World Bank, and this data is used in World Bank (1995) and Milanovic (1998). More recently, researchers at the World Bank have obtained the data for 1993-96. A sub-sample of the HBS is also now available through the Luxembourg Income Survey (LIS) for 1987, 1990 and 1992. Thus, no prior researchers have had access to the micro data for the entirety of the extended period that we examine.
} 
We restrict our earnings analysis sample to individuals between the ages of 18 and 60 who report that labor income is their principal income source. We deflate nominal earnings using the aggregate CPI (1992Q4=100) for the survey quarter until the end of 1992 and for the survey month thereafter. Prior to 1993, there were 7 education categories reported for individuals in the survey. Beginning in 1993, two of these categories (basic vocational training and some high school) were combined into a single category; for consistency, we combine these categories in a similar manner for the 1985-92 period. We also combined primary school and less than primary school into a single base category (among workers, the latter group is quite small), thereby yielding a total of 5 educational categories over the full sample.

Table 1 reports sample means for some of the variables used extensively in our analysis of wage inequality. ${ }^{18}$ The demographic characteristics of the cross-sectional samples remain quite stable during and after the transition. The means of the education dummies indicate a small increase in average levels of educational attainment in the 1990s. It is important to note the very high participation rate of women in Poland. They made up roughly $45 \%$ of the workforce prior to the start of the transition, and this rose to $48 \%$ by 1996.

Only $5 \%$ of the sample was employed in the private sector in 1988 , and this rises to $39 \%$ in 1996. As we noted above, self-employment grew tremendously in Poland in the early phase of the transition. A limitation of the HBS prior to the 1993 is that it contained an under representation of the self-employed. The redesign of the survey in 1993 was in part meant to rectify this problem. Thus, our data presumably understates private sector employment in the early transition period (1990-92).

\footnotetext{
${ }^{18}$ In 1992, half of the total sample was used to test the new monthly survey; these data were considered unreliable and not made available to us. In addition, a number of observations had to be left out due to incomplete data. The use of sampling weights helps maintain the representativeness of that year's data despite the fall in the sample size. Also note that the mean of the urban dummy rises sharply in 1992. This results from a reclassification of the "location" variable; we could not reconcile this fully with the classification used in prior years. Hence, the results for this variable should be interpreted with caution.
} 


\section{Changes in Earnings Inequality}

In this section, we examine changes in the distribution of earnings for individual workers. For the years 1994-1996, we use earnings measures that are adjusted (using the procedure described in the Appendix) for the increase in idiosyncratic variance that occurred with the shift to a monthly reporting period.

\section{IV.1 Measures of Overall Earnings Inequality}

The first panel of Table 2 reports 90-10 and 75-25 percentile differentials of log earnings for all workers. Earnings inequality is quite stable in the pre-transition years 1985-88, followed by a period of rapid growth in inequality that begins in 1989, the first year of transition (recall that the transition began in August 1989). Between 1988 and 1996, the log $90 / 10$ ratio increased from 0.97 to 1.12 . This is a $16 \%$ increase in the $90 / 10$ ratio $(\exp (0.15))$, which is sizeable for an 8-year period. The increase in the 75-25 percentile differential, from 0.50 in 1988 to 0.59 in 1996 , is also sizeable. ${ }^{19}$ It is interesting that the $90 / 10$ ratio seems to have flattened out in 1994-97, suggesting that earnings inequality has reached a plateau (although the 75/25 ratio continues to show slow growth).

Despite the growth in earnings inequality in Poland during the transition, the structure of earnings as of 1996 was still considerably more compressed than in the U.S. For instance, Juhn, Murphy and Pierce (1993) report that the $\log 90 / 10$ ratio for wages of full-time male workers in the U.S. was 1.46 in $1988 .{ }^{20}$ Interestingly, however, earnings differentials are greater in Poland than in certain continental European countries such as Germany in the 1990s (see Prasad, 2000).

In Table A1, we present results using an alternative measure of inequality - the Gini coefficient. It is evident that the patterns of changes in inequality revealed by the Gini are, in

\footnotetext{
${ }^{19}$ Finer breakdowns of the percentile differentials (not shown here) indicated that inequality was roughly equally distributed above and below the median before the transition. During the transition, inequality above the median, as measured by the 90-50 and 75-50 differentials, increased slightly more than inequality below the median (5010 and 50-25 differentials).

${ }^{20}$ For male workers alone, we obtain a 90/10 ratio of 1.15 in 1996 (see Table 7).
} 
general, quite similar to those indicated by the percentile ratios. For instance, the Gini coefficient for the full sample rises sharply from 0.221 in 1988 to 0.261 in 1996 . The Gini is relatively flat from 1994 through 1996, suggesting again that inequality has reached a plateau.

Our results for earnings inequality in the HBS differ in a number of important ways from the results of Atkinson and Micklewright (1992) and Rutkowski (1998), who used aggregated data from the census of enterprises conducted by the CSO each September. We do not find evidence of the sharp drop in inequality from 1986-89 that they report. And we find more modest increases in inequality after 1989. Starting from a base year of 1986 (when our figures roughly agree) and ending with 1995 (the final year in their analysis) we obtain a 16\% increase in the $90 / 10$ ratio and an 0.042 point increase in the Gini, while their figures imply $30 \%$ and 0.076 point increases, respectively. Given the much more representative population coverage of the HBS data, we view our results as more accurate.

As discussed earlier, we adjusted the earnings data for 1994-96 to account for the change in survey frequency. In the second panel of Table 1, we show the percentile ratios for 1994-96 based on the unadjusted data. Clearly, the adjustment makes a significant difference for our inferences regarding growth in inequality. For instance, if we ignored the shift to monthly reporting, we would conclude that the $90 / 10$ ratio increased by about $20 \%$ from 1988 to 1996 (as opposed to our preferred estimated of 16\%). Still, this figure remains well below the $30 \%$ figure that previous authors obtained using the September census of enterprises. Thus, our lower figure for the growth in earnings inequality arises primarily from our different data set, rather than from our adjustment procedure. $^{21}$

It is possible to get some sense of the accuracy of our adjustment for the change in survey frequency in 1993 using data from the Polish Labor Force Survey, which began in 1992. Using these data, Newell and Socha (1998) report that the 90/10 ratio for labor earnings

\footnotetext{
${ }^{21}$ Note also that our adjustment procedure only shifts the level of inequality measures in 1994-96, and does not alter their variation over time within those years. Thus, the profile of stable inequality over the period 1994-96 is not affected by whether or not the data are adjusted.
} 
was flat from 1992 to 1996 . Since we find about a 3\% increase in inequality over the same period, this suggests that our adjustment procedure is not overcompensating for the effect of the change in survey frequency. ${ }^{22}$

\section{IV.2 Earnings Inequality in the Public and Private Sectors}

In this section we compare the earnings distributions in the state and private sectors. The first four columns in the lower panel of Table 2 show log percentile ratios separately for workers employed in each sector. In absolute terms, inequality is higher in the private sector than in the public sector. However, whether inequality increased more in the private or public sector during the transition is ambiguous. For instance, from 1988 to 1996 , the $\log 90 / 10$ ratio rises from 0.96 to 1.05 in the public sector $(+10 \%)$ and from 1.04 to 1.19 in the private sector $(+16 \%)$. However, the $75 / 25$ ratio rises by 0.06 in the public sector and 0.05 in the private sector. A finer breakdown of the percentile differentials confirmed that, in the private sector, inequality increases have been greater above the median and, in particular, near the top end of the distribution.

In order to resolve the contradictory messages presented by the $90 / 10$ and $75 / 25$ ratios, and, more generally, to obtain a better understanding of changes in the shape of the entire earnings distribution in each sector, we next examine kernel density estimates. Figure 1 presents kernel density estimates for (log) real earnings for a few selected years $(1988,1992$, 1994 and 1996). ${ }^{23}$

In 1988 (pre-transition), the mode of the private sector earnings distribution was slightly to the right of that for the public sector. In fact, the private sector distribution almost

\footnotetext{
22 There appear to be important differences between the LFS and our HBS data. Newell and Socha report a log 90/10 ratio for monthly earnings in 1996 of 0.99 , which is very far below our value of 1.12 , and also extremely low by international standards. Also, they report a private sector (nonagricultural) employment share of $33 \%$ in 1996, while we find 39\% in the HBS data. In each instance, the HBS numbers seem more plausible. Of course, the LFS cannot be used to analyze changes in the structure of earnings from pre- to post-transition, because it does not commence until 1992.

${ }^{23}$ An Epanechnikov kernel with a bandwidth of 0.05 was used for the kernel density estimation. We also computed optimal bandwidths--these were generally in the range of 0.04-0.06 and made little difference to the density plots.
} 
stochastically dominated the public sector distribution, except for a small bump in the left tail. By 1992, there was not yet much change in this picture. But, by 1994, the situation was dramatically different. The mode of the private sector earnings distribution had shifted left, and the public sector distribution began to stochastically dominate. By 1996, the dominance of the public sector earnings distribution is even clearer.

Figure 2 (left panel) plots the differential between (unconditional) median private and public sector earnings. As we see, the median earnings in the private sector dropped from about $10 \%$ above that in the public sector in 1992 to about $12 \%$ below in $1994 .^{24}$ Compositional effects are important in driving these changes. Somewhat surprisingly, it is low education workers who have primarily shifted into the emerging private sector.

The top panel of Figure 3 examines the change in shape of the public sector earnings distribution from 1988 to 1996 . In order to focus on the change in shape, we scaled earnings to have the same mean in each year. ${ }^{25}$ It is obvious from the figure that inequality in the public sector earnings distribution increased. Most obviously, the mass near the mode clearly drops from 1988 to 1996 . At same time, some mass is shifted into the right tail, and the distribution becomes clearly skewed to the right.

The bottom panel of Figure 3 examines the change in shape of the private sector earnings distribution. The loss in mass near the mode is not obviously greater in the private sector than in the public sector. However, there is much more mass shifted into the extreme tails. This explains our earlier finding that when one looks at $75 / 25$ differentials it appears that inequality increased slightly more in the public sector, but when one looks at 90/10 ratios it appears that inequality increased more in the private sector.

\footnotetext{
${ }^{24}$ Earnings data from the Labor Force Survey reveal a similar pattern of a sharp decline in this differential during the transition. Newell and Socha (1998) report a mean private sector wage premium of 5 percent in 1992, falling to a negative differential of 10 percent by 1996.

${ }^{25}$ Note that percentile ratios, Gini coefficients and variances of log earnings are invariant to a proportional scaling of all earnings observations. Any sensible inequality measure should have this property, since, e.g., a change in the denomination of currency units should not alter inequality.
} 
To sum up, although the increase in earnings inequality was higher in the private sector (at least according to two of the three summary measures we examined), workers in public sector enterprises also experienced significant increases in earnings inequality during the transition. In other words, the rapid reallocation of labor from the public sector to the private sector cannot by itself explain much of the increase in earnings inequality during the transition in Poland. We explore this more formally below.

\section{IV.3 Changes in the Structure of Employment and Earnings Inequality}

In this section we decompose the increase in overall earnings inequality into components attributable to changes in the composition of employment across sectors or industries versus increases in inequality within sectors or industries. Consider the following decomposition:

$$
\sigma_{t}^{2}=\sum_{j} s_{j t} \sigma_{j t}^{2}+\sum_{j} s_{j t}\left(w_{j t}-\bar{w}_{t}\right)^{2}
$$

where $\sigma_{t}^{2}$ is the cross-sectional variance of log hourly earnings, $s_{j t}$ is the employment share of sector $j, \sigma_{j t}^{2}$ is the within-sector variance of earnings, $w_{j t}$ is sector $j$ mean earnings, $\bar{w}_{t}$ is grand mean earnings in the sample, and the subscript $t$ is a time index. Using this formula, the change in variance over time can be decomposed into changes attributable to within- and between-sector components, as well as composition effects within and between sectors.

The top panel of Table 3 shows this variance decomposition based on the state and private sectors. ${ }^{26}$ The overall increase in log earnings variance from 1988 to 1996 is 7.00 (the figures in the table are multiplied by 100). Of this, 3.63 points, or $52 \%$, is due to increases in variance within the state and private sectors. 2.71 points or $39 \%$ of the increase in variance is

\footnotetext{
${ }^{26}$ Of course, there are two ways to decompose the change in variance, depending on whether one calculates the within sector component of the change in variance (i.e., the sum of the changes in sector specific variances weighted by sectoral employment shares) using the base period or terminal period sectoral employment shares. We use the base period employment shares as weights, which means that the change in variance in the state sector will dominate this term. If we use the terminal period shares instead, our conclusion that this is the most important term in the decomposition is strengthened.
} 
attributable to the shift of workers from the (relatively low variance) public sector to the private sector. Note that the two variance components that arise due to the differences in mean earnings between the two sectors (last two columns) are of minor importance.

These results suggest, somewhat surprisingly, that the shifting of workers from the state to the private sector, while important, is not the main factor driving increased earnings inequality during the Polish transition. Rather, within sector increases in earnings inequality constitute the most important factor driving the increase in overall earnings inequality. A key factor driving this result is that earnings inequality in the state sector has grown substantially, as we documented in sections $I V .1$ and $I V .2$. In 1996, the state sector still accounted for almost two-thirds of nonagricultural employment in Poland, so developments there remain critical for the shape of the overall earnings distribution. Despite the slow pace of privatization in Poland, work by Pinto et al (1993), Commander and Dhar (1998) and others suggests that substantial restructuring of SOEs has nevertheless occurred, as managers have responded to removal of government subsidies and import competition. This presumably led to increased earnings inequality in the state sector as that sector has moved closer to competitive wage setting.

Table 3 also breaks down the increase in overall earnings variance into sub-periods. Note that there were sharp increases in earnings variance from 1988 to 1992 and from 1992 to 1994, with a subsequent much more moderate increase from 1994 to 1996. It is interesting that composition effects were of almost no importance in the early transition period (1988-92). But in the most recent period, the shifting of workers from the public to the private sector was the main factor driving increased earnings inequality. As shown in Table 2, in 1994-96 earnings inequality reached a plateau in both the public and private sectors. Indeed, within sector earnings dispersion appears to have fallen marginally from 1994 to 1996 . Thus, compositional effects dominate the (modest) growth in earnings inequality during this latter period. ${ }^{27}$

The composition of employment by industry also changed dramatically from 1988 to 1996. For instance, as noted in the footnote to Table 3, the share of manufacturing dropped from $37.2 \%$ to $30.6 \%$. In the bottom panel of Table 3 we present a variance decomposition for

\footnotetext{
${ }^{27}$ The private sector share of total employment rose by 13 percentage points from 1992 to 1994 and by an additional 8 percentage points from 1994 to 1996 (see Table 1).
} 
13 broadly-defined industrial sectors of the economy. ${ }^{28}$ The key result is that virtually all of the increase in overall earnings variance is attributable to within-industry increases in variance. The between-industry component of the change in variance (due to changes in the relative means of earnings across industries) is positive in all three sub-periods, but is roughly offset by within- and between-industry composition effects. Thus, industry employment shifts do not seem to have played much of a role in influencing patterns of overall earnings dispersion. ${ }^{29}$

In summary, growth of earnings inequality within sectors and industries is the main source of increased overall earnings inequality. Labor reallocation from the public sector to the private sector has also contributed importantly to the rise in overall inequality. However, despite the large shifts in industry employment shares, inter-industry labor flows do not appear to have contributed directly to the rise in earnings inequality. These two sets of results are reconciled by the fact that, while industry shares of total employment changed significantly for only a few industries, increases in the shares of private sector employment within each industry were very large. ${ }^{30}$

\section{IV.4 Within-Group Earnings Inequality}

In this section we examine changes in within-group earnings inequality. First, we look at inequality within education groups, with workers classified into four groups: college degree, high school graduate, vocational training, and primary school. Table 4 reports log percentile ratios for workers in each group. Prior to the transition, the degree of inequality within each group (as measured by the $90 / 10$ and $75 / 25$ ratios) was quite similar.

\footnotetext{
${ }^{28}$ A change in industry classifications in 1993 vitiated our attempts to derive a consistent set of codes at a finer level of disaggregation for the full sample.

${ }^{29} \mathrm{We}$ also recomputed this decomposition restricting the sample to workers in the private sector and found that, again, virtually all of the increase in log wage variance could be attributed to changes in within-industry inequality rather than composition effects. Thus, within industry wage variation appears to dominate overall wage variation and both appear to have evolved in a similar pattern.

${ }^{30}$ For instance, the share of manufacturing and mining in total employment fell from 37.2 percent in 1988 to 30.6 percent in 1996. Over this period, the share of private sector employment in this industry rose sharply, from 5.9 percent to 43.5 percent. Similarly, while the share of trade, hotels and restaurants in total employment rose from 9.6 percent in 1988 to 11.5 percent in 1996, the share of private sector employment within this industry jumped from 4.2 percent to 70.4 percent over this period.
} 
During the transition, inequality grew at quite different rates within these four education groups. From 1988 to 1996 , the $\log 90 / 10$ ratio increased by $0.18,0.12,0.05$ and 0.09 , respectively, within the four groups. And the $\log 75 / 25$ ratio increased by $0.12,0.08$, 0.05 and 0.03 , respectively. Thus, workers with college degrees experience by far the greatest increase in inequality during the transition by either measure. For workers with only basic vocational training or a primary school degree, the increases in within-group inequality were much more modest. Thus, increases in within-group inequality seem to be a prominent feature of the transition mainly for highly educated workers.

Based on our earlier findings, one might surmise that the explanation for these results is that better-educated workers were more likely to migrate to private sector, where inequality is higher. Indeed, the private sector employment shares of all education groups rose sharply during the transition. But, somewhat surprisingly, movement into the private sector was most pronounced for workers with lower levels of education. ${ }^{31}$ Hence, differential patterns of reallocation of labor across the public and private sectors cannot explain our finding. ${ }^{32}$

The finding that within-group inequality grew much more rapidly for more educated workers during the transition in Poland is in sharp contrast to the experiences of the U.S. and U.K. in the 1970s and 1980s, where inequality grew by comparable levels within all education groups (for the U.S., see Juhn, Murphy and Pierce, 1993, and Gould, Moav and Weinberg, 2001; for the U.K., see Machin, 1996, and Machin and Van Reenen, 1998). Thus, explaining this pattern is a theoretical challenge for models of transition.

Next, we examine the evolution of inequality within broadly defined (synthetic) experience groups. Table 5 (top panel) reports log percentile ratios for groups of workers with

\footnotetext{
${ }^{31}$ The shares of private sector employment in 1988 and 1996, calculated separately for each group, are as follows: college degree (2.9 in 1988,19.4 in 1996); some college $(5.3,20.3)$; high school $(3.4,33.9)$; vocational training $(6.6,48.3)$; and primary school $(3.8,44.7)$.

${ }^{32} \mathrm{We}$ also directly examined the evolution of percentile differentials within educational groups for workers in the private and public sectors, respectively. The pattern of greater increases in within-group inequality for bettereducated workers was evident in both sectors.
} 
different experience levels (given how experience is defined, these are also age cohorts). There are fairly significant increases in inequality for all groups, consistent with the plausible interpretation of these increases as reflecting time effects. For instance, from 1988 to 1996, the $\log 90 / 10$ ratio rises by between 0.12 and 0.22 for all experience groups. Over the same period, the $75 / 25$ ratio rises by about 0.10 for all groups.

We also examined the evolution of overall inequality within birth cohorts. The middle panel of Table 5 reports log percentile ratios for synthetic cohorts defined on the basis of birth year. It is, of course, impossible to separate out age effects from time effects by looking at these differentials for any one cohort. ${ }^{33}$ But the fact that all cohorts experienced larger increases in inequality during the transition than during the pre-transition period, with a substantial fraction of this increase occurring between 1988-89 and 1992-4, suggests that time effects are important.

Note that the group of younger workers, born between the years of 1966 and 1975, experiences an increase of the 90/10 ratio from 0.75 in 1988 (when the oldest members of the cohort are 22) to 0.99 in 1992 (when the oldest members are 26). Much of this increase is presumably simply due to age effects. But it is worth noting that the within-cohort share of private sector employment (relative to total employment) during the transition is much greater for this cohort than for the older ones. ${ }^{34}$

As discussed above, it is impossible to disentangle age, cohort and time effects on overall inequality. But a plausible way to identify time effects was suggested by Juhn, Murphy and Pierce (1993, p. 424-6). Using the results in the top panel of Table 5, if we take the average (across age/experience groups) of changes in inequality between any two points in calendar time, we get changes that combine cohort and time effects. Using the results in the

\footnotetext{
${ }^{33}$ Typically, inequality tends to rise over the life cycle within a given cohort as employment histories, cumulative effects of individual productivity shocks, and other factors drive up within-cohort wage dispersion.

${ }^{34}$ The share of total employment in each cohort accounted for by private sector employment in 1994-96 (average) is as follows: $1926-35$ : $0.21 ; 1936-45: 0.24 ; 1946-55$ : $0.30 ; 1956-65: 0.34 ; 1966-75: 0.48 ; 1976-85: 0.76$. We do not report results in the table for cells with fewer than 100 observations.
} 
middle panel of Table 5, if we take the average (across cohorts) of changes in inequality between any two points in calendar time we get changes that combine age and time effects. So these two measures will have time effects in common. If they move together, it is plausible that they do so because time effects are the dominant factor (rather than because age and cohort effects just happen to be equal). The bottom panel of Table 5 shows that changes in inequality (for different sub-periods) are indeed quite similar when averaged across cohorts vs. age (experience) groups, suggesting that much of the increase in the dispersion of the overall earnings distribution can plausibly be attributed to time effects. ${ }^{35}$

\section{IV.5 Residual Earnings Inequality}

Another commonly used method to examine within-group earnings inequality is to regress earnings on observed attributes such as gender, education, and experience and to examine the dispersion of the residuals. These earnings residuals arguably control for betweengroup differences across many different group characteristics and indicate the evolution of inequality within narrowly defined groups.

Log percentile ratios for log earnings residuals are reported in the last (top right) panel of Table $2 .{ }^{36}$ Comparing these to the ratios for log earnings themselves, we see that about fourfifths of the level of overall earnings inequality is accounted for by within-group inequality. Changes in within-group inequality also account for a substantial fraction of the increase in overall inequality. For instance, the $\log 90 / 10$ ratio for the log earnings residuals increases by 0.09 from 1988 to 1996, which accounts for about $60 \%$ of the increase in total wage inequality over that period. This is similar to the experience of the U.S., where the change in residual

\footnotetext{
${ }^{35}$ Furthermore, as Juhn, Murphy and Pierce point out (p. 425), while the average (across cohorts) change in inequality combines age and time effects, taking the change in this measure over time causes the age effect to drop out. Thus, the increase in the growth rate of inequality we observe between the 1985-88 period and the 1988-92 period must be due to time effects. The same is true for the decrease in the growth rate of inequality we observe between 1988-92 and 1992-96.

${ }^{36}$ Wage residuals are from annual OLS regressions of earnings on a constant, four education dummies, experience and its square, and dummies for gender, urban residence, and employment in the private sector. These are identical to the specifications examined in greater detail in the regression analysis of section $\mathrm{V}$.
} 
inequality accounted for two-thirds of the total increase in wage inequality during the 1970s and 1980s (Juhn, Murphy and Pierce, 1993).

It is also interesting to compare the increases in residual earnings inequality in the public and private sectors. These results are reported in the last four columns in the bottom panel of Table 2. Note that the increase in residual earnings inequality was very similar in the two sectors. For instance, from 1988 to 1996 , the $\log 90 / 10$ percentile ratio increased by 0.05 in each sector. But, as we have already seen, the 90/10 ratio for the level of log earnings increased more in the private sector than in the public sector. As we will see in section $V$, the explanation for this is that inequality between education groups increased much more in the private sector, especially at the upper quantiles.

We next examined changes in residual inequality within specific education groups. To do this, we took the squared earnings residuals and regressed them on education group dummies and interactions of these dummies with time, along with controls for private sector, gender, and urban residence. The time trend interaction terms then capture changes over time in within-group inequality for each education group, controlling for other observed characteristics. Consistent with our earlier findings in section $I V .4$, the time trend for collegeeducated workers was substantially larger than that for the other groups. ${ }^{37}$ This confirms the relatively higher increase in inequality within this group, even after controlling for other observed characteristics. We also ran these type of regressions separately for public and private sector workers, and, in each sector, the time trend was much larger for the college educated group. ${ }^{38}$

\footnotetext{
${ }^{37}$ The time trend is 0.063 for the college-educated group (standard error $=0.004$ ). It is 0.009 for the some-college group (not significant), 0.032 for the high school group, 0.008 for the vocational training group, and 0.015 for the primary school group.

${ }^{38}$ In the public sector, the time trend is 0.056 for the college-educated group, 0.031 for the high school group, 0.018 for the vocational training group, and 0.008 for the primary school group. In the private sector, the time trend is 0.101 for the college-educated group, 0.025 for the high school group, -0.004 for the vocational training group, and 0.025 for the primary school group. The trend for the some-college group was insignificant in both sectors.
} 
To summarize, we find that the increase in within-group inequality accounts for about $60 \%$ of the total increase in earnings inequality during the Polish transition - which is similar to the experiences of the U.S. and other industrial economies in the 1970s and 1980s. However, there are some important differences across groups. In particular, within-group inequality rose significantly among highly educated workers but increased far less for workers with lower levels of formal education. And within-group inequality accounts for less than half the overall increase in inequality within the private sector where (as we will see in section $V$ ) between-group changes were more important.

\section{IV.6 The Behavior of Extreme Quantiles}

Appendix Table A1 also reports variances of log earnings as an alternative inequality measure. From 1988 to 1996 the variance of log earnings increased by 0.07 , which was a $47 \%$ increase. This is far greater than the $16 \%$ increase in the $90 / 10$ ratio, or the $18 \%$ increase in the Gini, that we have emphasized earlier. The reason is that the variance is much more sensitive to behavior in the tails of the distribution.

In order to focus more on what happened in the tails, Table 6 reports a set of extreme quantile ratios and compares them to the $90 / 10$ ratio. Clearly inequality as measured by the log 99/1 ratio increased much more substantially. In fact, the log 99/1 ratio increased from 1.82 in 1988 to 2.40 in 1996, which corresponds to a $79 \%$ increase in the 99/1 ratio itself.

If we decompose the increase in the $\log 99 / 1$ ratio into the increases in the $99 / 50$ and $50 / 1$ ratios, we see that the latter increased by 0.22 and 0.36 , respectively. This suggests that the majority of the increase in the $99 / 1$ ratio is actually due to increased inequality at the low end of the earnings distribution.

Not surprisingly, the 99/1 ratio increased much more dramatically in the private sector $(+118 \%)$ than the in the public sector $(+26 \%)$. This is consistent with our earlier results in section $I V .2$ that increases in inequality near the mode were similar in the two sectors, but that the private sector saw a greater increase in mass in the extreme tails. Much of this is due to an increase in the number of very low earnings individuals in the private sector. 
Finally, it is also interesting to look at the variance of the residuals from log earnings equations, which are also reported in Table A1. Note that residual variance increased by $39 \%$ from 1988 to 1996, which is somewhat less than the increase in the overall earnings variance. Hence, the fraction of earnings variance that is within group declined slightly, from $72 \%$ in 1988 to $68 \%$ in 1996 . This is again consistent with the dramatic increase in inequality between education groups, especially in the private sector, that we document in detail in section $V .^{39}$

\section{IV.7 Earnings Inequality Among Men and Women}

Next, we examine the evolution of earnings inequality among men and women. Most of the literature on earnings inequality in the U.S. and U.K. has focused only on male earnings inequality. This omission has been largely driven by the fact that prime age men have very high employment rates, while women have much lower employment rates and are more likely to enter and exit from employment over time. Thus, the study of earnings inequality among women confronts severe selection problems, which must be dealt with by modeling women's employment decisions (a difficult task).

But in Poland, women have traditionally had employment rates nearly as high as those for men, and in our sample they make up $45 \%$ to $48 \%$ of employed workers. Thus, we feel it is not too implausible to study earnings inequality for women in Poland just as it has typically been done for men in the U.S. and U.K., as we have done in this paper. In this section we analyze the evolution of earnings inequality for men and women separately, and also examine their respective impacts on the overall earnings distribution.

Table 7 shows log percentile ratios separately for men and women. As in many other countries in the 1980s and 1990s, the increase in male earnings inequality is greater than the increase in inequality among women. For instance, from 1988 to 1996, the 90/10 percentile

\footnotetext{
${ }^{39}$ It is also interesting to examine the variance of log wages and log wage residuals separately for the public and private sectors. From 1988 to 1996, the variance of log earnings increased from .146 to $.180(+23 \%)$ in the public sector and from .165 to $.260(+58 \%)$ in the private sector. For the residuals, these same changes were from .106 to $.125(+18 \%)$ and from .136 to $.188(+36 \%)$ respectively. Note that the increases in overall variance are greater than the increases in residual variance, particularly in the private sector. There, the fraction of variance that is residual drops from $82 \%$ in 1988 to $72 \%$ in 1996.
} 
ratio goes from 0.94 to 1.15 for men (a $23 \%$ increase) and from 0.85 to 1.00 for women (a $16 \%$ increase). Similarly, the increase in the 75-25 differential from 1988-96 is 0.12 for men and 0.07 for women. To put the $23 \%$ increase in the $90 / 10$ ratio for men from 1988 to 1996 in perspective, it is the same as the $23 \%$ increase in the $90 / 10$ ratio for male wages in the U.S. in the 1980s reported by Juhn, Murphy and Pierce (1993).

It is worth noting that the increase in male earnings inequality is greater than the increase in overall inequality, a phenomenon that has been documented for numerous other countries as well during the 1980s and 1990s. For instance, Fortin and Lemieux (2000) show that, for the U.S. in the 80 s and 90 s, the male and female wage distributions moved much closer together (both in terms of their means and overall shape), and that this was a force acting to reduce inequality in the overall wage distribution. They argue that, except for changes around the minimum wage (which declined substantially in real terms), the overall wage distribution in the U.S. was very stable during the 1980s.

We examined whether any similar phenomenon occurred in Poland. Figure 4 presents employment-share weighted kernel density estimates for the real earnings of men and women for the years 1988, 1992, 1994 and 1996. It is hard to discern any tendency for the two distributions to converge over time. Throughout the period 1988-96, the female earnings distribution is to the left of the male earnings distribution at virtually all percentile points.

The right panel of Figure 2 (right panel) shows that the median earnings differential between men and women fell from about $30 \%$ to about $20 \%$ during the early stages of transition, but then rebounded and, after 1992, has stabilized at around 25 percent. Although the earnings premium for men is higher in the private sector in the early years of transition, it, too, levels off at about 25 percent after 1992. This is in sharp contrast to the experiences of many industrial countries, where the gender wage differential has declined substantially over the last few decades.

Evidence from other transition economies is more in line with that for industrial countries. For instance, Hunt (2002) reports that German unification resulted in a 10 
percentage point decline in the gender wage gap in the former East Germany but notes that this was accompanied by a much greater decline in female employment than in male employment. She also finds that low earners were more likely to leave employment after unification and that these low earners were disproportionately female. In Poland, by contrast, our evidence suggests that the relative share of women in total employment actually increased slightly during the transition (see Table 1). Thus, there appear to be very different forces at work in Poland in terms of influences on the gender earnings gap.

\section{Regression Analysis of the Structure of Earnings}

In this section, we conduct a regression analysis of the structure of earnings to gain more insight into changes in between-group earnings inequality during the transition. In Table 8, we present estimates of standard human capital earnings functions (see Willis, 1986) for a selected set of years during the 1985-1996 period. ${ }^{40}$ The coefficients on the educational category dummies show that premia for educational qualifications increased substantially during the transition. For instance, the college degree coefficient increases from 0.383 in 1988 to 0.527 in 1992 and further to 0.683 in 1996. This implies that the college premium (relative to primary school, which is the omitted group) was approximately 47 percent in 1987, 69 percent in 1992, and 98 percent in 1996. The high school premia for the same three years are 23, 30 and 41 percent, respectively. Note that this implies a widening of the college-high school premium as well. These results also imply that, by 1996, the high school and college premia in Poland were toward the high end of estimates typically obtained using data from Western countries.

Our findings of a sharp increase in education premia during the transition are consistent with those of Gorecki (1994), based on his examination of aggregate Polish earnings data, and

\footnotetext{
${ }^{40}$ We continue to use the adjusted data for 1994-96. However, whether we use adjusted or unadjusted data makes no difference to the point estimates of the regression coefficients since the OLS regressions are essentially identical to those used in the first stage regressions for the adjustment procedure.
} 
of authors who have examined the structure of earnings in other transition economies. For instance, Ham, Svejnar, and Terrell (1995) examine surveys conducted by the Federal Ministry of Labor in Czechoslovakia in 1988 and 1991. They find that the wage gap between university and elementary school graduates increased from 58\% in 1988 to $63 \%$ in 1991 . Brainerd (1998) examines survey data for Russia and reports that, from 1991 to 1994, the return to a year of education rose from $3.1 \%$ to $6.7 \%$ for men and from $5.4 \%$ to $9.6 \%$ for women.

One interesting question is whether academic qualifications acquired in the communist era have the same value in the labor market as more recently acquired qualifications. Unfortunately, it is difficult to answer this question decisively with our sample, since it ends in 1996, seven years after the big bang. As a first pass, we constructed a dummy variable for individuals who, based on their age and imputed years of education, attained their highest degree on or after 1992. This dummy, and its interactions with the education dummies, did not show any strong evidence that recent degrees command a premium relative to older degrees. ${ }^{41}$

Since (potential) labor market experience (age-years of education-6) enters the regressions as a quadratic, returns to experience need to be evaluated at specific levels of experience. The OLS estimates imply a decline in experience premia in the early years of the transition, followed by a subsequent rebound. ${ }^{42}$ For instance, for workers with 25 years of potential labor market experience, the return to an additional year of experience is 0.41 percent in 1988 , drops to 0.36 percent in 1990 and then rises to 0.48 percent by 1996 . For younger workers with 5 years of potential experience, this return drops from 2.64 percent in 1988 to 2.46 percent in 1990 and then partially recovers to 2.52 percent by 1996 .

The returns to experience that we estimate for Polish workers are much smaller than those found in Western data sets. For instance, for prime-age workers with 15 years of

\footnotetext{
${ }^{41}$ It has been suggested to us by some Polish observers that major curriculum changes in the post-Communist era have taken place mainly at the university level. There is also some debate about whether the level of rigor in school and university programs has improved in the post-communist era, with some actually arguing the opposite.

${ }^{42}$ Lehmann and Wadsworth (1998) report similar results for Poland as well as Russia.
} 
experience, our estimates for 1994-96 imply that the return to an additional year of experience is about 1.5 percent. Estimates for the U.S., from Blau and Kahn (1997), show that the comparable number for 1988 is in the range of 2.4 percent (women) to 2.8 percent (for men).

Consistent with the evidence from the previous section, the earnings premium for men relative to women drops by about 5 percentage points in the early years of transition, but then rises again and stabilizes at around 30 percent after 1992. The earnings premium for workers in urban areas relative to those in rural areas, on the other hand, almost doubles by the mid1990s relative to pre-transition levels.

Until 1992, the survey contains a question that can be used to determine if the respondent worked for a privately owned firm. For the 1994-96 surveys, this question is refined, so we can determine if the respondent works for one of three types of privately-owned firms: small firms (including the self-employed); large privately-held firms; and large mixedownership firms with majority ownership by the private sector. So, in the later years, we include separate dummies for these three categories.

In the years up until 1992, the private sector dummy coefficient is always significantly positive, and generally around 0.08 . Recall from Figure 2 that the unconditional private sector earnings premium was around 10\% from 1985 to 1992, but that this premium turned sharply negative in 1994-1996. Our results for 1994-1996 indicate that earnings of workers in small private firms were about 10\% below those of similar workers (controlling for observed education, experience, etc.) in the public sector. ${ }^{43}$ But workers in large private firms (including large foreign-owned firms) earn approximately 20 percent more than observationally similar workers in the public sector, while people who work for large firms with mixed but majority private ownership earn about 11 percent more. A separate dummy for employment in mixed-

\footnotetext{
43 "Small private firms" includes the self-employed.
} 
ownership firms with majority state ownership was small and not significant. ${ }^{44}$

We also ran regressions separately for workers in the public and private sectors. Some of the main results, and a comparison with the results for the full sample, are summarized in Figure 5. Two aspects of the results are worth noting. First, education premia rose much more sharply in the private sector during the transition. Prior to the transition, the college and high school premia were quite similar in the two sectors (about 40 and 20 percent, respectively). By 1996, these premia had risen to about 60 percent and 30 percent, respectively, in the public sector, and to about 90 percent and 40 percent, in the private sector.

The second interesting aspect is that, for older workers (25 years of potential labor market experience) in the private sector, the return to an additional year of experience was close to zero before the transition. After the transition, this return begins to rise and, by 1996, is close to 0.6 percent, even higher than in the public sector ( 0.4 percent). We conjecture that this reflects selection effects and the fact that experienced workers who were able to obtain private sector employment after the transition have strong unobserved attributes. For younger workers (5 years of potential labor market experience), the returns to an additional year of experience are in the range of 2.5-3.0 percent in both sectors before the transition. By 1996, this return declines to 2.3 percent in the private sector and rises marginally to 2.7 percent in the public sector. One possible explanation for this pattern is that the relative supply of younger workers looking for private sector jobs rose sharply during the transition, thereby driving down the returns to experience (at low levels of experience). This is consistent with the figures presented earlier showing that the most recent birth cohort in our dataset has a disproportionately large share of private sector employment.

We also computed the earnings regressions separately for men and women. To conserve space, we do not report those results in detail. One intriguing finding from this set of

\footnotetext{
${ }^{44}$ We also ran the regressions for 1994-96 with just an overall private sector dummy. The estimated coefficient was in the range of -0.08 to -0.10 in 1994-96. This is similar to, although slightly smaller than, the sharp reversal of the (unconditional) private sector earnings premium after 1992 shown in Fig. 2.
} 
regressions was that, before the transition, education premia were substantially higher for women than for men. For instance, in 1988, the college and high school premia (relative to a primary school degree) for women were 58 percent and 30 percent, respectively, compared to 38 percent and 16 percent, respectively, for men. By 1996, these premia for both men and women had converged to about 95 percent and 40 percent. Thus, although both men and women experienced substantial increases in education premia during the transition, these increases were much greater, in relative terms, for men than for women.

The roles of selection effects and changes in patterns of labor supply for male and female workers with different skill attributes in explaining these differences remain to be investigated. Another possibility, especially given the sharper increases in education premia in the private sector noted earlier, is that men have disproportionately benefited from employment growth in the private sector. Interestingly, a cursory examination of the data strongly refutes this hypothesis. Although the share of women and men in public sector employment has remained roughly equal over our entire sample, the share of private sector employment accounted for by women in fact rose from about 20 percent before the transition to about 40 percent by 1996.

\section{V.1 Quantile Regressions}

Next, we follow Buchinsky (1994) in noting that a more complete picture of the evolution of returns to different skill characteristics can be obtained by use of quantile regression. This enables us to characterize in a parsimonious way the changes in the entire conditional distribution of earnings. We ran quantile regressions of log real quarterly (monthly for 1994-96) labor earnings on the same set of regressors as in the OLS regressions. Regressions were run for the $0.10,0.25,0.50,0.75$ and 0.90 quantiles.

Table 9 reports the college and high school premia (relative to primary school) obtained from the quantile regressions. Note that the college premium jumps sharply from 1988 to 1996 at all quantile points. For example, median earnings were approximately 48 percent $(\exp (0.39))$ higher for college graduates than primary school graduates in 1988, and 
this premium increases to 95 percent $(\exp (0.67))$ by 1996 .

It is interesting that the increase in the college premium is relatively greater at higher quantiles. By 1996, the college premium is considerably greater at both the 0.75 and 0.90 quantiles than it is at the median. At the 0.90 quantile, it is as high as 120 percent.

The high school premium also rises substantially from 1988 to 1996 at all quantile points. For example, median income was approximately 20 percent higher for high school graduates compared to primary school graduates in 1988, and this premium increases to 43 percent in 1996. The levels of the high school premium, and its behavior during the transition years, are quite similar across quantiles.

When we ran the quantile regressions limiting the sample to private sector workers, we found greater increases in the levels of college premia by 1996 at all quantile points. For instance, in 1996 the college premium was about 150 percent at the median of the distribution and over 170 percent at the 0.90 quantile. The high school premium is also higher in the private sector, although only marginally. By 1996, the pattern of distribution across quantiles of college premia (higher at the upper quantiles) and high school premia (similar across quantiles) in the private sector is quite similar to that in the full economy.

Overall, the quantile regressions reveal a rather interesting pattern in terms of how education premia changed during the transition. While the changes in the high school premium were similar at different points of the distribution, the growth of the college premium was markedly greater at higher quantiles.

Table 10 shows returns to experience, evaluated at 5,15 and 25 years. As noted earlier, these returns to experience are smaller than those found in Western data sets. This is true both before and after the big bang. The numbers in Table 10 are in percentage terms. So, for example, in 1986, for workers with 5 years of experience, an additional year of experience raises earnings by about 2.9 percent at the (conditional) median of the earnings distribution. For the U.S., Buchinsky (1994) reports a corresponding figure of 4.97 percent for 1985, which is about 70 percent higher. For those with 15 years of experience, the return to experience at 
the median in 1986 is smaller (1.67 percent) and, for those with 25 years of experience, it is even smaller ( 0.42 percent). The results are similar at other quantile points. In contrast, Buchinsky (1994) finds returns to experience for U.S. workers with 15 years of experience to be about 2.9 to 3.0 percent at all quantile points in 1985 , nearly double the figure for Poland.

A break is apparent after the big bang. In 1990, returns to experience dropped relative to their pre-transition levels. This is true at almost all quantile points for workers with 5 or 15 years of experience. In the 1992-1996 period, there is some recovery in experience returns, especially at higher experience levels. In 1996, the returns to experience at the 25-year experience level range from 0.59 percent at the 0.10 quantile down to 0.41 percent at the 0.90 quantile. These figures are much higher than those for 1990, especially at the lower quantiles. After 1991, experience premia are relatively stable for workers with 15 years of experience but continue to decline for younger workers with only 5 years of experience. Thus, somewhat surprisingly, recent labor market entrants are the only group for whom experience returns are systematically lower in 1996 than in 1987.

In earlier work (Keane and Prasad, 2002), we have noted the marked increase in the relative generosity of pensions in 1991-92 and the consequent surge in the pension rolls in those years. Indeed, in our sample, the share of total employment accounted for by workers in the 51-60 age group fell from about 13 percent in 1989-90 to 11 percent in 1991-92 and, further, to 9 percent by 1996. In other words, it is possible that self-selection of workers with weaker unobserved attributes into retirement could account for the recovery in experience premia observed in the mid-1990s at higher experience levels.

The key finding from this section is that the returns to general human capital, as measured by education premia, rose markedly during the transition while the returns to experience declined in the early years of the transition. This is consistent with the notion of rapid obsolescence of firm- or industry-specific skills during a period of rapid industrial restructuring (see Svejnar, 1996). Workers with higher levels of general human capital are better able to adapt to such changes. Our results also reveal important differences between the 
structure of earnings in Poland and that in industrial economies. By 1996, education premia had risen to a level in line with, if not somewhat greater than, those found in many industrial economies. But, compared to countries like the U.S., the divergence in returns to experience became, in some respects, larger than before the transition.

\section{Conclusion}

This paper has analyzed changes in the structure of earnings in Poland over the period 1985-96. This period covers the last few years of the pre-transition era, the "big bang" in 198990, and six subsequent years of transition. In our view, it is particularly important to document what happened during the Polish transition, because Poland has (so far) been the most successful of all the transition countries.

As expected, we found that earnings inequality rose substantially during the transition. We also expected to find that most of this increase was attributable to substantial reallocation of labor from the state-owned sector, where wages are compressed because they are not set competitively, to a dynamic private sector that exhibits much greater earnings inequality - a view consistent with the framework in Aghion and Commander (1999), for example. But, to our surprise, we found that the largest single factor driving increased earnings inequality was the growth of within sector inequality. Indeed, inequality within the state-owned sector itself grew substantially.

The main area where Poland has lagged behind other transition economies is in the pace of privatization of state-owned enterprises (SOEs). Indeed, the state sector still accounted for over $60 \%$ of total nonagricultural employment by $1996 .{ }^{45}$ But a number of authors, including Pinto et al (1993) and Commander and Dhar (1998), have argued that substantial restructuring of SOEs has occurred even in the absence of privatization. Our findings of increased earnings inequality within the state sector, including substantially increased education premia, are consistent with this view, since they suggest that the state sector has indeed moved closer to having a competitive wage structure.

\footnotetext{
${ }^{45}$ The pace of privatization has accelerated more recently - see OECD (2000).
} 
Our results indicate that education premia grew substantially during the transition, by about $50 \%$ in the state sector and $100 \%$ in the private sector. Presumably, a key factor driving increasing returns to skill in Poland is simply the rising fraction of firms engaged in competitive wage setting. As this fraction grows - both through increase in the size of the private sector and restructuring of SOEs - the relative demand for skilled labor will increase in the economy as a whole. Through this mechanism, education premia are driven up in both the private and public sectors during the transition.

In contrast to education premia - which increased to the point where they now appear to be at least as great as those observed in the U.S. and U.K. - experience premia in Poland have not systematically increased, and remain very low relative to levels observed in the advanced Western economies. This is consistent with the notion of rapid obsolescence of firm- or industry-specific skills during a period of rapid industrial restructuring (see Svejnar, 1996).

We also found that increases in within-group inequality account for about $60 \%$ of the overall increase in earnings inequality. These results are similar to those for industrial economies such as the U.S. and the U.K. that experienced large increases in both between- and within-group inequality during the 1980s. However, one striking finding is that increases in within-group inequality appear to have been much greater for highly educated workers in Poland. By contrast, in the U.S. and the U.K., virtually all skill groups experienced large increases in within-group inequality, and there is evidence that increases in inequality were actually greater within low education groups (see Gould, Moav and Weinberg, 2001). Thus, it is a challenge for models of transition to generate this pattern of greater increases in inequality among more educated workers. 


\section{Appendix Accounting for the Change in Survey Frequency after 1992}

Most aspects of the HBS, including the two stage sampling scheme and the structure of the survey instrument, were left unchanged during the transition. However, a few refinements were introduced in 1993. While most of these modifications were relatively minor, one important change was that, starting in 1993, households were surveyed for only one month rather than for a full quarter in an attempt to further improve survey response rates. The change in survey frequency has important implications for the purposes of measuring changes in cross-sectional inequality. In this appendix, we develop a technique for adjusting the 19941996 earnings data for the increased variability that may be attributable to the shift from quarterly to monthly reporting.

We begin by assuming the following statistical model for earnings:

$$
Y_{h t}=\alpha_{1 \mathrm{t}}+\beta_{\mathrm{t}} \mathrm{X}_{\mathrm{ht}}+\sigma_{\mathrm{t}} \varepsilon_{\mathrm{ht}}
$$

where $Y_{h t}$ is labor income of person $h$ in period $t, X_{h t}$ is a vector of individual-specific characteristics used to predict labor income, and $\varepsilon_{\mathrm{ht}}$ is the unpredictable or idiosyncratic component of labor income scaled to have a standard deviation of unity. The time-specific standard deviation that scales the idiosyncratic component of labor income is denoted by $\sigma_{t}$. Our objective is to estimate the increase in $\sigma_{\mathrm{t}}$ for the 1994-96 period that is due solely to the switch to a monthly reporting interval.

We begin by estimating equation (1) separately for each quarter during 1985-1992 and each month for the period 1994-1996. ${ }^{46}$ The variables included in $\mathrm{X}_{\mathrm{ht}}$ are controls for education level, experience and its square, sex, urban residence, and sector of occupation. A key feature of the results is that the $\mathrm{R}^{2}$ values drop sharply after the shift to monthly reporting in 1994. Presumably, the bulk of this drop is due to greater idiosyncratic variability of income, as well as greater relative importance of measurement error, when income is reported at monthly rather than quarterly frequencies.

Next, we assume that the standard deviation of the residuals from estimation of equation (1) follow the process:

$$
\begin{array}{r}
\ln \sigma_{\mathrm{t}}=\pi_{0}+\pi_{1} \mathrm{t}+\pi_{2} \mathrm{t}^{2}+\pi_{3} \mathrm{t}^{3}+\pi_{4} \mathrm{YB}_{\mathrm{t}}+\pi_{5} \mathrm{PVTSHR}_{\mathrm{t}}+\pi_{6} \mathrm{I}[\mathrm{t}>96]+\eta_{\mathrm{t}} \\
\mathrm{t}=2,4, \ldots, 95 ; \mathrm{t}=109,110, \ldots, 144 .
\end{array}
$$

Here $t$ is a monthly time index. For the years 1985 through 1992, the data are quarterly, so $t$ is

\footnotetext{
${ }^{46}$ These results are not reported in the paper but are available from the authors. As noted earlier, individual earnings data are not available in the HBS for 1993.
} 
assigned as the midpoint of the interval covered by each quarter (that is, $t=2,4, \ldots, 95$ ). The variable $I[t>96]$ is an indicator for the post-1992 period in which the data is monthly. Thus, $\pi_{6}$ captures the structural shift in the error standard deviation attributable to the shift to a monthly data frequency. The time polynomials capture the evolution of the error standard deviation over time due to changes in within-group income inequality, controlling for the group characteristics included in $\mathrm{X}_{\mathrm{ht}}$. The term $\mathrm{YB}_{\mathrm{t}}$ controls for the effect of changes in mean income on the error standard deviation. PVTSHR $_{t}$ is the share of total employment in the private sector. This share increased markedly after the transition (see Table 1) and, given that earnings inequality tends to be higher in the private sector, could be an important determinant of overall earnings inequality. Finally, $\eta_{\mathrm{t}}$ captures purely idiosyncratic period-specific changes in income variability. Note that, since we do not have earnings data for 1993, we assume smooth adjustment from the end of 1992 through the beginning of 1994, with no discrete breaks in the intervening year.

After estimating the first and second stage equations, we adjust labor income data for 1994-1996 to account for the increase in the idiosyncratic variance that we estimate occurred solely due to the shift to a monthly reporting period after 1992 . We define adjusted income for the 1994-96 period as:

$$
\mathrm{YA}_{\mathrm{ht}}=\alpha_{1 \mathrm{t}}+\beta_{\mathrm{t}} \mathrm{X}_{\mathrm{ht}}+\left\{\sigma_{\mathrm{t}} / \exp \left(\pi_{6}\right)\right\} \hat{\epsilon}_{\mathrm{ht}} \quad \mathrm{t}=109,110, \ldots, 144 .
$$

Here $\hat{\epsilon}_{\mathrm{ht}}$ is the estimated residual from equation (1) and $\pi_{6}$ is our estimate from equation (2) of the increase in the log of the residual standard deviation due to the switch to monthly income reporting.

The scale factor $\exp \left(\pi_{6}\right)$ that we estimated was 1.051. This implies that the change in survey frequency results in an estimated increase of about 5 percent in the residual error variance. Thus, even though employed workers (a majority of whom are salaried) have reasonably stable labor earnings streams, there is still a significant increase in earnings variability in going from a quarterly to a monthly frequency.

Interestingly, the corresponding adjustment factor that we estimated in Keane and Prasad (2002) for total incomes of worker-headed households was 1.179. One would indeed expect the variability of household income (and household labor earnings) to be higher than for individual employed workers. Note that we observe wages for workers only if they are employed. On the other hand, we do observe zero labor incomes for worker households. This, in addition to variability in employment status among household members, suggests that there is likely to be greater cross-sectional variability in labor earnings and total income of households compared to the sample of employed workers. Furthermore, as the estimated adjustment factors indicate, the increase in cross-sectional variability at higher frequencies is greater for households than for individual employed workers. 


\section{References}

Acemoglu, Daron (1998) "Why Do New Technologies Complement Skills? Directed Technical Change and Wage Inequality," Quarterly Journal of Economics, Vol. 113, pp. 1055-89.

Aghion, Philippe, and Simon Commander (1999) "On the Dynamics of Inequality in the Transition," Economics of Transition, Vol. 7, pp. 275-98.

Aghion, Philippe, Peter Howitt and Gianluca Violante (2000) "General Purpose Technology and Within-Group Inequality," Manuscript, University College, London.

Atkinson, Anthony B., and John Micklewright (1992) Economic Transformation in Eastern Europe and the Distribution of Income, Cambridge University Press.

Blau, Francine D. and Lawrence M. Kahn (1997) "Swimming Upstream: Trends in the Gender Wage Differential in the 1980s," Journal of Labor Economics, 15:1, pp. 1-42.

Brainerd, Elizabeth (1998) "Winners and Losers in Russia's Economic Transition," American Economic Review, Vol. 88, pp. 1094-1116.

Buchinsky, Moshe (1994) "Changes in the U.S. Wage Structure 1963-1987: Application of Quantile Regression,” Econometrica, Vol. 62, pp. 405-58.

Caselli, Francesco (1999) “Technological Revolutions,” American Economic Review, Vol. 89, pp. 78-102.

Commander, Simon and Sumana Dhar (1998), "Enterprises in the Polish Transition," in Enterprise Restructuring and Unemployment in Models of Transition, Simon Commander (ed.) (Washington, DC: The World Bank), pp. 109-142.

Commander, Simon and Andrei Tolstopiatenko (1998), "The Role of Unemployment and Restructuring in the Transition," in Enterprise Restructuring and Unemployment in Models of Transition, Simon Commander (ed.) (Washington, DC: The World Bank), pp. 169-192.

Coricelli, Fabrizio, Krzysztof Hagemejer, and Krzysztof Rybinski (1995), "Poland" in Unemployment, Restructuring and the Labor Market in Eastern Europe and Russia, Simon Commander and Fabrizio Coricelli (eds.) (Washington, DC: The World Bank).

Flanagan, Robert (1995) "Wage Structures in the Transition of the Czech Economy," IMF Staff Papers, Vol. 42, pp. 836-54. 
Fortin, Nicole M., and Thomas Lemieux (2000) “Are Women's Wage Gains Men's Losses? A Distributional Test," AER Papers and Proceedings, Vol. 90, pp. 456-60.

Freeman, Richard, and Remco Oostendorp (2000) "Wages Around the World: Pay Across Occupations and Countries," NBER Working Paper No. 8058.

Frydman, Roman and Andrzej Rapaczynski (1994) Privatization in Eastern Europe: Is the State Withering Away?, London: Central European University Press.

Galor, Oded, and Omer Moav (2000) “Ability-Biased Technological Transition, Wage Inequality, and Economic Growth" Quarterly Journal of Economics, Vol. 115, pp. 469-97.

Garner, Thesia, and Katherine Terrell (1998) "A Gini Decomposition of Inequality in the Czech and Slovak Republics During the Transition," Economics of Transition, Vol. 6, pp. 23-46.

Gorecki, Brunon (1994) "Evidence of a New Shape of Income Distribution in Poland," Eastern European Economics, pp. 32-51.

Gould, Eric D., Omer Moav, and Bruce A. Weinberg (2001) "Precautionary Demand for Education, Inequality, and Technological Progress," Journal of Economic Growth, Vol. 6, pp. 285-315.

Ham, John C., Jan Svejnar, and Katherine Terrell (1995) "Czech Republic and Slovakia," in Unemployment, Restructuring and the Labor Market in Eastern Europe and Russia, Simon Commander and Fabrizio Coricelli (eds.) (Washington, DC: The World Bank).

Hunt, Jennifer (2002) "The Transition in East Germany: When is a Ten Point Fall in the Gender Wage Gap Bad News," Journal of Labor Economics, Vol. 20, pp. 148-69.

Juhn, Chinhui, Kevin M. Murphy, and Brooks Pierce (1993) "Wage Inequality and the Rise in Returns to Skill,” Journal of Political Economy, Vol. 101, pp. 410-42.

Keane, Michael P., and Eswar S. Prasad (2002) "Inequality, Transfers and Growth: New Evidence from the Economic Transition in Poland," Review of Economics and Statistics, forthcoming.

Keane, Michael P., and Eswar S. Prasad (1996) "The Employment and Wage Effects of Oil Price Changes: A Sectoral Analysis," Review of Economics and Statistics, 78:3, 389399.

Krusell, Per, Lee E. Ohanian, José-Víctor Ríos-Rull, and Giovanni Violante (2000) "CapitalSkill Complementarity and Inequality: A Macroeconomic Analysis," Econometrica, Vol. 68, pp. 981-95. 
Lehmann, Hartmut and Jonathan Wadsworth (2000) "Tenures that Shook the World: Worker Turnover in Russia, Poland, and Britain," Journal of Comparative Economics, Vol. 28, pp. 639-64.

Machin, Stephen (1996) "Wage Inequality in the U.K.," Oxford Review of Economic Policy, Vol. 12, pp. 47-64.

Machin, Stephen, and John Van Reenen (1998) "Technology and Changes in Skill Structure: Evidence from Seven OECD Countries," Quarterly Journal of Economics, Vol. 113, pp. 1215-44.

Milanovic, Branko (1998) "Income, Inequality and Poverty during the Transition from Planned to Market Economy," World Bank Regional and Sectoral Studies (Washington, DC: World Bank).

Newell, Andrew, and Mieczyslaw Socha (1998) "Wage Distribution in Poland: The Roles of Privatization and International Trade, 1992-96," Economics of Transition, Vol. 6, pp. 47-65.

Newell, Andrew (2001) “The Distribution of Wages in Transition Countries," IZA Discussion Paper No. 267 (Bonn, Germany: IZA).

OECD “OECD Economic Surveys: Poland” various years (Paris, France: OECD).

Orazem, Peter F., and Milan Vodopivec (1995) "Winners and Losers in Transition: Returns to Education, Experience, and Gender in Slovenia," World Bank Economic Review, Vol. 9, pp. 201-30.

Pinto, Brian, Marek Belka, and Stefan Krajewski (1993) "Transforming State Enterprises in Poland: Evidence on Adjustment by Manufacturing Firms," Brookings Papers on Economic Activity, pp. 213-70.

Prasad, Eswar S. (2000) "The Unbearable Stability of the German Wage Structure: Evidence and Interpretation," IMF Working Paper No. 00/22.

Rutkowski, Jan (1996a) "High Skills Pay Off: The Changing Wage Structure During the Economic Transition in Poland," Economics of Transition, Vol. 4, pp. 89-112.

Rutkowski, Jan (1996b) "Changes in the Wage Structure During Economic Transition in Central and Eastern Europe,” World Bank Technical Paper No. 340.

Rutkowski, Jan (1998) "Welfare and the Labor Market in Poland," World Bank Technical Paper No. 417. 
Svejnar, Jan (1991) "Microeconomic Issues in the Transition to a Market Economy," Journal of Economic Perspectives, Vol. 5, pp. 123-38.

Svejnar, Jan (1996) "Enterprises and Workers in the Transition: Econometric Evidence," American Economic Review Papers and Proceedings, Vol. 86, pp. 123-27.

Violante, Giovanni (2002) "Skill Transferability, Technological Acceleration and the Rise in Residual Wage Inequality," Quarterly Journal of Economics, forthcoming.

Willis, Robert J. (1986) "Wage Determinants: A Survey and Reinterpretation of Human Capital Earnings Functions," in Handbook of Labor Economics, Vol. 1, (eds.) Orley Ashenfelter and Richard Layard (Amsterdam: North Holland). 
Table 1. Sample Means for Selected Years: Wage Analysis Sample

\begin{tabular}{|c|c|c|c|c|c|c|c|c|c|c|}
\hline & & & 1988 & 1989 & 1990 & 1991 & 1992 & 1994 & 1995 & 1996 \\
\hline \multicolumn{3}{|c|}{ College degree } & 0.09 & 0.09 & 0.09 & 0.10 & 0.11 & 0.12 & 0.11 & 0.12 \\
\hline \multicolumn{3}{|c|}{ Some college } & 0.01 & 0.01 & 0.01 & 0.00 & 0.00 & 0.03 & 0.03 & 0.03 \\
\hline \multicolumn{3}{|c|}{ High school } & 0.31 & 0.31 & 0.32 & 0.34 & 0.35 & 0.34 & 0.34 & 0.35 \\
\hline \multicolumn{3}{|c|}{ Vocational training } & 0.38 & 0.39 & 0.40 & 0.39 & 0.39 & 0.38 & 0.39 & 0.38 \\
\hline \multicolumn{3}{|c|}{ Primary school } & 0.21 & 0.21 & 0.18 & 0.16 & 0.14 & 0.13 & 0.13 & 0.12 \\
\hline \multicolumn{3}{|c|}{ Experience } & 20.95 & 21.39 & 21.26 & 20.87 & 21.25 & 20.44 & 20.66 & 20.55 \\
\hline \multicolumn{3}{|c|}{ Experience $^{\wedge} 2$} & 5.37 & 5.54 & 5.47 & 5.24 & 5.36 & 5.10 & 5.19 & 5.17 \\
\hline \multicolumn{3}{|c|}{ Male } & 0.55 & 0.55 & 0.55 & 0.55 & 0.55 & 0.53 & 0.53 & 0.52 \\
\hline \multicolumn{3}{|l|}{ Urban } & 0.64 & 0.63 & 0.64 & 0.65 & 0.79 & 0.74 & 0.72 & 0.72 \\
\hline \multicolumn{3}{|c|}{ Private sector } & 0.05 & 0.06 & 0.09 & 0.13 & 0.18 & 0.31 & 0.35 & 0.39 \\
\hline \multicolumn{11}{|c|}{ Number of observations (households) } \\
\hline 1985 & 17,927 & 1988 & 21,114 & & 1991 & 19,025 & & 1995 & 26,316 & \\
\hline 1986 & 19,666 & 1989 & 20,787 & & 1992 & 7,259 & & 1996 & 26,165 & \\
\hline 1987 & 21,574 & 1990 & 20,685 & & 1994 & 26,095 & & & & \\
\hline
\end{tabular}

Notes: The wage analysis sample includes workers between the ages of 18 and 60 who report a positive wage and who report that labor income was their primary source of income. 
Table 2. Percentile Differentials

\begin{tabular}{|c|c|c|c|c|c|c|c|c|}
\hline & \multicolumn{2}{|c|}{ All Workers } & \multicolumn{2}{|c|}{$\begin{array}{c}\text { All Workers } \\
\text { Unadjusted Data }\end{array}$} & \multicolumn{2}{|c|}{$\begin{array}{c}\text { All Workers } \\
\text { Wage Residuals } \\
\end{array}$} & & \\
\hline & $90-10$ & $75-25$ & $90-10$ & $75-25$ & $90-10$ & $75-25$ & & \\
\hline 1985 & 0.96 & 0.49 & - & - & 0.78 & 0.40 & & \\
\hline 1986 & 0.97 & 0.50 & - & - & 0.79 & 0.40 & & \\
\hline 1987 & 0.96 & 0.49 & -- & -- & 0.78 & 0.40 & & \\
\hline 1988 & 0.97 & 0.50 & & & 0.82 & 0.42 & & \\
\hline 1989 & 1.04 & 0.53 & - & - & 0.89 & 0.46 & & \\
\hline 1990 & 1.03 & 0.52 & -- & -- & 0.90 & 0.46 & & \\
\hline 1991 & 1.03 & 0.53 & - & - & 0.86 & 0.44 & & \\
\hline 1992 & 1.08 & 0.56 & -- & - & 0.92 & 0.46 & & \\
\hline 1994 & 1.11 & 0.56 & 1.15 & 0.58 & 0.92 & 0.46 & & \\
\hline 1995 & 1.12 & 0.58 & 1.16 & 0.60 & 0.92 & 0.46 & & \\
\hline \multirow[t]{3}{*}{1996} & 1.12 & 0.59 & 1.15 & 0.61 & 0.91 & 0.46 & & \\
\hline & \multicolumn{2}{|c|}{ Public Sector } & \multicolumn{2}{|c|}{ Private Sector } & \multicolumn{2}{|c|}{$\begin{array}{c}\text { Public Sector } \\
\text { Wage Residuals }\end{array}$} & \multicolumn{2}{|c|}{$\begin{array}{c}\text { Private Sector } \\
\text { Wage Residuals }\end{array}$} \\
\hline & $90-10$ & $75-25$ & $90-10$ & $75-25$ & $90-10$ & $75-25$ & $90-10$ & $75-25$ \\
\hline 1985 & 0.95 & 0.49 & 1.03 & 0.53 & 0.78 & 0.40 & 0.94 & 0.49 \\
\hline 1986 & 0.96 & 0.49 & 1.01 & 0.54 & 0.79 & 0.40 & 0.81 & 0.45 \\
\hline 1987 & 0.96 & 0.49 & 1.08 & 0.54 & 0.78 & 0.39 & 0.85 & 0.46 \\
\hline 1988 & 0.96 & 0.49 & 1.04 & 0.56 & 0.81 & 0.42 & 0.95 & 0.47 \\
\hline 1989 & 1.03 & 0.53 & 1.14 & 0.61 & 0.88 & 0.45 & 0.97 & 0.53 \\
\hline 1990 & 1.02 & 0.52 & 1.12 & 0.60 & 0.89 & 0.45 & 1.01 & 0.55 \\
\hline 1991 & 1.00 & 0.51 & 1.16 & 0.61 & 0.84 & 0.43 & 0.99 & 0.51 \\
\hline 1992 & 1.06 & 0.55 & 1.15 & 0.57 & 0.91 & 0.46 & 0.96 & 0.47 \\
\hline 1994 & 1.06 & 0.54 & 1.19 & 0.61 & 0.87 & 0.44 & 1.03 & 0.51 \\
\hline 1995 & 1.08 & 0.57 & 1.19 & 0.57 & 0.89 & 0.45 & 1.00 & 0.49 \\
\hline 1996 & 1.05 & 0.55 & 1.19 & 0.61 & 0.86 & 0.43 & 1.00 & 0.49 \\
\hline
\end{tabular}

Notes: The percentile differentials reported above are for log quarterly (1985-92) or monthly (1994-96) earnings. The data for 1994-96 are adjusted for the change in survey frequency after 1992, unless indicated otherwise. Wage residuals are from annual OLS regressions of earnings on a constant, four education dummies, experience and its square, and dummies for gender, urban residence, and employment in the private sector. 
Table 3. Effects of Sectoral Shifts on Changes in Wage Inequality (Variance Decomposition)

\begin{tabular}{|c|c|c|c|c|c|}
\hline \multirow[b]{2}{*}{ Period } & \multirow[b]{2}{*}{$\begin{array}{c}\text { Total Change } \\
\text { in Variance }\end{array}$} & \multicolumn{2}{|c|}{ Within Sector } & \multicolumn{2}{|c|}{ Between Sector } \\
\hline & & $\begin{array}{c}\text { Change in } \\
\text { Variance }\end{array}$ & $\begin{array}{c}\text { Composition } \\
\text { Effect }\end{array}$ & $\begin{array}{c}\text { Change in } \\
\text { Variance }\end{array}$ & $\begin{array}{c}\text { Composition } \\
\text { Effect }\end{array}$ \\
\hline $1988-96$ & 7.00 & 3.63 & 2.71 & 0.44 & 0.23 \\
\hline 1988-92 & 2.69 & 2.30 & 0.32 & 0.00 & 0.06 \\
\hline $1992-94$ & 3.61 & 1.59 & 1.73 & 0.17 & 0.12 \\
\hline \multirow[t]{2}{*}{$1994-96$} & 0.70 & -0.26 & 0.66 & 0.27 & 0.05 \\
\hline & & \multicolumn{2}{|c|}{ Within Industry } & \multicolumn{2}{|c|}{ Between Industry } \\
\hline Period & $\begin{array}{l}\text { Total Change } \\
\text { in Variance }\end{array}$ & $\begin{array}{c}\text { Change in } \\
\text { Variance }\end{array}$ & $\begin{array}{c}\text { Composition } \\
\text { Effect }\end{array}$ & $\begin{array}{c}\text { Change in } \\
\text { Variance }\end{array}$ & $\begin{array}{c}\text { Composition } \\
\text { Effect }\end{array}$ \\
\hline $1988-96$ & 7.00 & 6.76 & -0.41 & 0.89 & -0.23 \\
\hline $1988-92$ & 2.69 & 2.39 & 0.21 & 0.21 & -0.10 \\
\hline $1992-94$ & 3.61 & 3.52 & -0.21 & 0.19 & 0.09 \\
\hline $1994-96$ & 0.70 & 0.85 & -0.41 & 0.49 & -0.22 \\
\hline
\end{tabular}

Notes: Variance (of log wages) and its components multiplied by 100. For the results in the first panel, workers were classified into one of two sectors - private or public. For the second panel, workers were classified into 13 broadly defined sectors. These sectors and their employment shares in 1988 and 1996 are as follows: manufacturing and mining $(37.2,30.6)$; construction $(8.7,8.0)$; agriculture, forestry, and fishing $(11.7,4.7)$; transport and communications $(8.5,8.5)$; trade, hotels, and restaurants $(9.6,11.5)$; real estate and housing $(3.7,3.0)$; science and technology $(1.0,0.7)$; education and culture $(8.6,9.7)$; health and hygiene $(5.6,8.5)$; recreation and tourism $(0.7,1.2)$; public administration $(2.5$, $7.2)$; finance and insurance $(0.9,2.5)$; and other services $(1.2,3.8)$. 
Table 4. Within-Group Inequality: Percentile Differentials

\begin{tabular}{|c|c|c|c|c|}
\hline & \multicolumn{2}{|c|}{ College Degree } & \multicolumn{2}{|c|}{ High School } \\
\hline & $90-10$ & $75-25$ & $90-10$ & $75-25$ \\
\hline 1985 & 0.87 & 0.46 & 0.89 & 0.46 \\
\hline 1986 & 0.88 & 0.44 & 0.90 & 0.46 \\
\hline 1987 & 0.87 & 0.46 & 0.92 & 0.47 \\
\hline 1988 & 0.96 & 0.50 & 0.91 & 0.46 \\
\hline 1989 & 0.95 & 0.50 & 0.98 & 0.51 \\
\hline 1990 & 0.95 & 0.48 & 0.95 & 0.49 \\
\hline 1991 & 0.98 & 0.50 & 0.95 & 0.49 \\
\hline 1992 & 1.03 & 0.54 & 1.00 & 0.52 \\
\hline 1994 & 1.14 & 0.62 & 1.03 & 0.53 \\
\hline 1995 & 1.15 & 0.62 & 1.04 & 0.54 \\
\hline \multirow[t]{3}{*}{1996} & 1.14 & 0.62 & 1.03 & 0.54 \\
\hline & \multicolumn{2}{|c|}{ Vocational Training } & \multicolumn{2}{|c|}{ Primary School } \\
\hline & $90-10$ & $75-25$ & $90-10$ & $75-25$ \\
\hline 1985 & 0.99 & 0.50 & 0.90 & 0.47 \\
\hline 1986 & 0.99 & 0.50 & 0.94 & 0.49 \\
\hline 1987 & 0.98 & 0.50 & 0.93 & 0.47 \\
\hline 1988 & 0.98 & 0.50 & 0.93 & 0.47 \\
\hline 1989 & 1.04 & 0.52 & 0.97 & 0.51 \\
\hline 1990 & 1.03 & 0.52 & 0.93 & 0.48 \\
\hline 1991 & 1.00 & 0.51 & 0.91 & 0.45 \\
\hline 1992 & 1.05 & 0.55 & 0.93 & 0.49 \\
\hline 1994 & 1.05 & 0.55 & 0.92 & 0.47 \\
\hline 1995 & 1.04 & 0.54 & 0.99 & 0.48 \\
\hline 1996 & 1.03 & 0.55 & 1.02 & 0.50 \\
\hline
\end{tabular}

Notes: The percentile differentials reported above are for log quarterly (1985-92) or monthly (1994-96) earnings. The data for 1994 96 are adjusted for the change in survey frequency after 1992. 
Table 5. Wage Inequality Within Synthetic Experience Groups and Cohorts

\begin{tabular}{|c|c|c|c|c|c|c|c|c|c|c|c|c|}
\hline \multirow{3}{*}{ Year: } & & \multicolumn{5}{|c|}{$\underline{90-10 \text { differential }}$} & \multicolumn{6}{|c|}{$\underline{75-25 \text { differential }}$} \\
\hline & & \multicolumn{5}{|c|}{ Experience Group } & \multicolumn{5}{|c|}{ Experience Group } & \\
\hline & & $0-10$ & $11-20$ & $21-30$ & $31-40$ & $41-50$ & $0-10$ & $11-20$ & $21-30$ & $31-40$ & $41-50$ & \\
\hline 1985 & & 0.93 & 0.92 & 0.93 & 0.91 & 0.89 & 0.46 & 0.47 & 0.46 & 0.48 & 0.42 & \\
\hline 1986 & & 0.99 & 0.95 & 0.93 & 0.94 & 0.84 & 0.49 & 0.49 & 0.47 & 0.47 & 0.42 & \\
\hline 1987 & & 0.98 & 0.97 & 0.92 & 0.89 & 0.82 & 0.50 & 0.49 & 0.46 & 0.45 & 0.43 & \\
\hline 1988 & & 0.93 & 0.96 & 0.94 & 0.92 & 0.81 & 0.44 & 0.50 & 0.48 & 0.47 & 0.45 & \\
\hline 1989 & & 1.03 & 1.03 & 1.01 & 0.99 & 0.90 & 0.52 & 0.53 & 0.51 & 0.51 & 0.49 & \\
\hline 1990 & & 1.05 & 1.03 & 1.02 & 0.98 & 0.91 & 0.53 & 0.53 & 0.52 & 0.49 & 0.50 & \\
\hline 1991 & & 0.99 & 1.04 & 1.01 & 0.99 & 0.99 & 0.49 & 0.53 & 0.52 & 0.50 & 0.49 & \\
\hline 1992 & & 1.05 & 1.09 & 1.08 & 0.98 & 1.03 & 0.55 & 0.56 & 0.54 & 0.54 & 0.55 & \\
\hline 1994 & & 1.07 & 1.12 & 1.14 & 1.06 & 0.97 & 0.52 & 0.56 & 0.58 & 0.54 & 0.54 & \\
\hline 1995 & & 1.04 & 1.14 & 1.15 & 1.11 & 1.00 & 0.49 & 0.59 & 0.59 & 0.58 & 0.54 & \\
\hline \multirow[t]{2}{*}{1996} & & 1.05 & 1.10 & 1.15 & 1.11 & 1.03 & 0.54 & 0.59 & 0.60 & 0.59 & 0.53 & \\
\hline & \multicolumn{6}{|c|}{$\underline{\text { Cohort }}$} & \multicolumn{6}{|c|}{$\underline{\text { Cohort }}$} \\
\hline Year: & 1926-35 & 1936-45 & 1946-55 & 1956-65 & 1966-75 & $\geq 1976$ & 1926-35 & 1936-45 & $1946-55$ & $1956-65$ & 1966-75 & $\geq 1976$ \\
\hline 1985 & 0.92 & 0.90 & 0.92 & 0.92 & 0.79 & - - & 0.48 & 0.45 & 0.47 & 0.47 & 0.37 & - - \\
\hline 1986 & 0.93 & 0.92 & 0.94 & 0.97 & 0.77 & - - & 0.46 & 0.47 & 0.48 & 0.50 & 0.39 & - - \\
\hline 1987 & 0.86 & 0.91 & 0.94 & 0.96 & 0.80 & - - & 0.45 & 0.45 & 0.48 & 0.49 & 0.40 & - - \\
\hline 1988 & 0.89 & 0.96 & 0.94 & 0.96 & 0.75 & -- & 0.47 & 0.47 & 0.48 & 0.48 & 0.40 & -- \\
\hline 1989 & 0.97 & 1.02 & 1.01 & 1.03 & 0.89 & - - & 0.51 & 0.52 & 0.52 & 0.51 & 0.45 & - - \\
\hline 1990 & 0.98 & 1.01 & 1.02 & 1.02 & 0.96 & - - & 0.51 & 0.51 & 0.52 & 0.52 & 0.46 & - - \\
\hline 1991 & 1.00 & 1.03 & 1.01 & 0.99 & 0.93 & - - & 0.56 & 0.52 & 0.52 & 0.51 & 0.45 & - - \\
\hline 1992 & 1.06 & 1.02 & 1.09 & 1.05 & 0.99 & -- & 0.54 & 0.55 & 0.54 & 0.55 & 0.49 & -- \\
\hline 1994 & -- & 1.07 & 1.11 & 1.13 & 1.05 & 0.78 & -- & 0.53 & 0.55 & 0.57 & 0.51 & 0.28 \\
\hline 1995 & - - & 1.11 & 1.11 & 1.16 & 1.06 & 0.79 & - - & 0.57 & 0.58 & 0.59 & 0.51 & 0.33 \\
\hline \multirow[t]{2}{*}{1996} & - - & 1.12 & 1.11 & 1.12 & 1.07 & 0.88 & - - & 0.58 & 0.57 & 0.60 & 0.56 & 0.37 \\
\hline & & & 1985-88 & 1988-92 & $1992-96$ & & & & 1985-88 & 1988-92 & $1992-96$ & \\
\hline \multirow{2}{*}{\multicolumn{3}{|c|}{$\begin{array}{l}\text { Avg. change within exper. groups: } \\
\text { Avg. change within cohorts: }\end{array}$}} & 0.00 & 0.13 & 0.04 & & & & 0.01 & 0.08 & 0.02 & \\
\hline & & & 0.02 & 0.14 & 0.06 & & & & 0.01 & 0.08 & 0.04 & \\
\hline
\end{tabular}

Notes: The percentile differentials reported above are for log quarterly (1985-92) or monthly (1994-96) earnings. The data for 1994-96 are

adjusted for the change in survey frequency that occured after 1992. Cohorts are defined on the basis of year of birth. Results are reported only for cell sizes greater than 100 . 
Table 6. Extreme Percentile Differentials

\begin{tabular}{lccccccc}
\hline & & $90-10$ & $95-5$ & $97-3$ & $99-1$ & $99-50$ & $50-1$ \\
\hline \multirow{2}{*}{ All Workers: } & 1988 & 0.97 & 1.28 & 1.48 & 1.82 & 1.03 & 0.79 \\
& 1996 & 1.12 & 1.49 & 1.81 & 2.40 & 1.25 & 1.15 \\
& & & & & & & \\
Private Sector: & 1988 & 1.04 & 1.37 & 1.56 & 1.93 & 0.95 & 0.98 \\
& 1996 & 1.19 & 1.71 & 2.06 & 2.71 & 1.36 & 1.34 \\
& & & & & & & \\
Public Sector: & 1988 & 0.96 & 1.27 & 1.47 & 1.82 & 1.04 & 0.78 \\
& 1996 & 1.05 & 1.39 & 1.60 & 2.05 & 1.17 & 0.88 \\
\hline
\end{tabular}

Notes: The percentile differentials reported above are for log quarterly (1985-92) or monthly (1994-96) earnings. The data for 1994-96 are adjusted for the change in survey frequency after 1992. 
Table 7. Percentile Differentials by Gender

\begin{tabular}{|c|c|c|c|c|c|c|c|c|}
\hline \multirow[b]{3}{*}{ Year: } & \multicolumn{4}{|c|}{ Log Wage } & \multicolumn{4}{|c|}{ Wage Residuals } \\
\hline & \multicolumn{2}{|c|}{ Men } & \multicolumn{2}{|c|}{ Women } & \multicolumn{2}{|c|}{ Men } & \multicolumn{2}{|c|}{ Women } \\
\hline & 90-10 & $75-25$ & $90-10$ & $75-25$ & $90-10$ & $75-25$ & $90-10$ & $75-25$ \\
\hline 1985 & 0.92 & 0.45 & 0.84 & 0.43 & 0.84 & 0.42 & 0.71 & 0.37 \\
\hline 1986 & 0.91 & 0.46 & 0.86 & 0.44 & 0.85 & 0.42 & 0.74 & 0.38 \\
\hline 1987 & 0.91 & 0.45 & 0.85 & 0.43 & 0.82 & 0.42 & 0.73 & 0.38 \\
\hline 1988 & 0.94 & 0.47 & 0.85 & 0.44 & 0.87 & 0.44 & 0.76 & 0.39 \\
\hline 1989 & 1.00 & 0.51 & 0.97 & 0.51 & 0.93 & 0.46 & 0.86 & 0.45 \\
\hline 1990 & 1.01 & 0.52 & 0.98 & 0.50 & 0.94 & 0.48 & 0.86 & 0.43 \\
\hline 1991 & 1.02 & 0.53 & 0.95 & 0.48 & 0.92 & 0.47 & 0.80 & 0.40 \\
\hline 1992 & 1.07 & 0.55 & 0.99 & 0.51 & 0.97 & 0.49 & 0.84 & 0.43 \\
\hline 1994 & 1.14 & 0.58 & 0.99 & 0.50 & 0.99 & 0.50 & 0.85 & 0.42 \\
\hline 1995 & 1.13 & 0.60 & 0.99 & 0.50 & 0.99 & 0.50 & 0.85 & 0.43 \\
\hline \multirow[t]{3}{*}{1996} & 1.15 & 0.59 & 1.00 & 0.51 & 0.98 & 0.51 & 0.84 & 0.41 \\
\hline & \multicolumn{4}{|c|}{ Public Sector } & \multicolumn{4}{|c|}{ Private Sector } \\
\hline & \multicolumn{2}{|c|}{ Men } & \multicolumn{2}{|c|}{ Women } & \multicolumn{2}{|c|}{ Men } & \multicolumn{2}{|c|}{ Women } \\
\hline Year: & $\underline{90-10}$ & $75-25$ & $\underline{90-10}$ & $75-25$ & $90-10$ & $75-25$ & $\underline{90-10}$ & $75-25$ \\
\hline 1985 & 0.91 & 0.45 & 0.84 & 0.43 & 0.99 & 0.51 & 0.81 & 0.49 \\
\hline 1986 & 0.91 & 0.46 & 0.86 & 0.44 & 0.90 & 0.47 & 0.91 & 0.46 \\
\hline 1987 & 0.90 & 0.44 & 0.85 & 0.43 & 1.00 & 0.47 & 0.97 & 0.51 \\
\hline 1988 & 0.93 & 0.47 & 0.85 & 0.44 & 1.02 & 0.53 & 0.89 & 0.50 \\
\hline 1989 & 0.99 & 0.50 & 0.97 & 0.50 & 1.05 & 0.57 & 1.11 & 0.62 \\
\hline 1990 & 0.99 & 0.50 & 0.98 & 0.50 & 1.11 & 0.59 & 1.02 & 0.54 \\
\hline 1991 & 0.98 & 0.51 & 0.94 & 0.48 & 1.11 & 0.59 & 1.06 & 0.55 \\
\hline 1992 & 1.05 & 0.54 & 0.98 & 0.51 & 1.13 & 0.56 & 1.05 & 0.46 \\
\hline 1994 & 1.08 & 0.56 & 0.94 & 0.47 & 1.22 & 0.62 & 1.06 & 0.52 \\
\hline 1995 & 1.08 & 0.58 & 0.94 & 0.48 & 1.16 & 0.60 & 1.07 & 0.51 \\
\hline 1996 & 1.05 & 0.55 & 0.94 & 0.48 & 1.20 & 0.63 & 1.08 & 0.51 \\
\hline
\end{tabular}

Notes: The percentile differentials reported above are for log quarterly (1985-92) or monthly (1994-96) earnings. The data for 1994. 96 are adjusted for the change in survey frequency after 1992. Wage residuals are from annual OLS regressions of earnings on a constant, four education dummies, experience and its square, and dummies for gender, urban residence, and employment in the private sector. 
Table 8. OLS Earnings Regressions

\begin{tabular}{|c|c|c|c|c|c|c|c|c|c|}
\hline & 1986 & 1988 & 1989 & 1990 & 1991 & 1992 & 1994 & 1995 & 1996 \\
\hline College degree & $\begin{array}{c}0.368^{*} \\
(0.009)\end{array}$ & $\begin{array}{c}0.383^{*} \\
(0.009)\end{array}$ & $\begin{array}{c}0.430^{*} \\
(0.010)\end{array}$ & $\begin{array}{r}0.497^{*} \\
(0.011)\end{array}$ & $\begin{array}{c}0.550^{*} \\
(0.010)\end{array}$ & $\begin{array}{c}0.527^{*} \\
(0.018)\end{array}$ & $\begin{array}{c}0.636^{*} \\
(0.010)\end{array}$ & $\begin{array}{c}0.632^{*} \\
(0.010)\end{array}$ & $\begin{array}{r}0.683^{*} \\
(0.010)\end{array}$ \\
\hline Some college & $\begin{array}{c}0.225^{*} \\
(0.027)\end{array}$ & $\begin{array}{c}0.229^{*} \\
(0.025)\end{array}$ & $\begin{array}{c}0.270^{*} \\
(0.032)\end{array}$ & $\begin{array}{r}0.394 * \\
(0.031)\end{array}$ & $\begin{array}{r}0.408^{*} \\
(0.034)\end{array}$ & $\begin{array}{l}0.334^{*} \\
0.058\end{array}$ & $\begin{array}{c}0.349^{*} \\
(0.014)\end{array}$ & $\begin{array}{c}0.348^{*} \\
(0.015)\end{array}$ & $\begin{array}{r}0.386^{*} \\
(0.014)\end{array}$ \\
\hline High school & $\begin{array}{c}0.180^{*} \\
(0.007)\end{array}$ & $\begin{array}{c}0.205^{*} \\
(0.007)\end{array}$ & $\begin{array}{c}0.209^{*} \\
(0.008)\end{array}$ & $\begin{array}{r}0.238^{*} \\
(0.008)\end{array}$ & $\begin{array}{r}0.276^{*} \\
(0.008)\end{array}$ & $\begin{array}{r}0.264^{*} \\
(0.014)\end{array}$ & $\begin{array}{c}0.306^{*} \\
(0.008)\end{array}$ & $\begin{array}{c}0.308^{*} \\
(0.008)\end{array}$ & $\begin{array}{r}0.343 * \\
(0.008)\end{array}$ \\
\hline Basic vocational training & $\begin{array}{c}0.132 * \\
(0.007)\end{array}$ & $\begin{array}{c}0.135^{*} \\
(0.007)\end{array}$ & $\begin{array}{c}0.115^{*} \\
(0.007)\end{array}$ & $\begin{array}{c}0.106^{*} \\
(0.008)\end{array}$ & $\begin{array}{c}0.112^{*} \\
(0.008)\end{array}$ & $\begin{array}{c}0.120^{*} \\
(0.014)\end{array}$ & $\begin{array}{c}0.149^{*} \\
(0.008)\end{array}$ & $\begin{array}{c}0.151^{*} \\
(0.008)\end{array}$ & $\begin{array}{r}0.165^{*} \\
(0.008)\end{array}$ \\
\hline Experience & $\begin{array}{c}0.035^{*} \\
(0.001)\end{array}$ & $\begin{array}{c}0.032 * \\
(0.001)\end{array}$ & $\begin{array}{c}0.036^{*} \\
(0.001)\end{array}$ & $\begin{array}{r}0.030^{*} \\
(0.001)\end{array}$ & $\begin{array}{r}0.030^{*} \\
(0.001)\end{array}$ & $\begin{array}{c}0.029 * \\
(0.002)\end{array}$ & $\begin{array}{c}0.030^{*} \\
(0.001)\end{array}$ & $\begin{array}{c}0.030^{*} \\
(0.001)\end{array}$ & $\begin{array}{r}0.030^{*} \\
(0.001)\end{array}$ \\
\hline Experience sqrd./100 & $\begin{array}{l}-0.062 * \\
(0.002)\end{array}$ & $\begin{array}{l}-0.056^{*} \\
(0.002)\end{array}$ & $\begin{array}{l}-0.065^{*} \\
(0.002)\end{array}$ & $\begin{array}{l}-0.052 * \\
(0.002)\end{array}$ & $\begin{array}{l}-0.050^{*} \\
(0.002)\end{array}$ & $\begin{array}{l}-0.048^{*} \\
(0.004)\end{array}$ & $\begin{array}{l}-0.053^{*} \\
(0.002)\end{array}$ & $\begin{array}{l}-0.052^{*} \\
(0.002)\end{array}$ & $\begin{array}{l}-0.051^{*} \\
(0.002)\end{array}$ \\
\hline Male & $\begin{array}{c}0.326^{*} \\
(0.005)\end{array}$ & $\begin{array}{c}0.301 * \\
(0.005)\end{array}$ & $\begin{array}{c}0.280^{*} \\
(0.005)\end{array}$ & $\begin{array}{r}0.247^{*} \\
(0.005)\end{array}$ & $\begin{array}{r}0.243 * \\
(0.005)\end{array}$ & $\begin{array}{r}0.260^{*} \\
(0.009)\end{array}$ & $\begin{array}{c}0.293^{*} \\
(0.005)\end{array}$ & $\begin{array}{c}0.302^{*} \\
(0.005)\end{array}$ & $\begin{array}{r}0.299 * \\
(0.005)\end{array}$ \\
\hline Urban & $\begin{array}{c}0.052^{*} \\
(0.005)\end{array}$ & $\begin{array}{c}0.071^{*} \\
(0.005)\end{array}$ & $\begin{array}{l}0.042 * \\
(0.005)\end{array}$ & $\begin{array}{r}0.046^{*} \\
(0.005)\end{array}$ & $\begin{array}{r}0.058^{*} \\
(0.005)\end{array}$ & $\begin{array}{c}0.095^{*} \\
(0.011)\end{array}$ & $\begin{array}{c}0.126^{*} \\
(0.005)\end{array}$ & $\begin{array}{c}0.115^{*} \\
(0.005)\end{array}$ & $\begin{array}{r}0.115^{*} \\
(0.005)\end{array}$ \\
\hline Private enterprise & $\begin{array}{c}0.075^{*} \\
(0.014)\end{array}$ & $\begin{array}{c}0.059^{*} \\
(0.012)\end{array}$ & $\begin{array}{c}0.067^{*} \\
(0.111)\end{array}$ & $\begin{array}{r}0.082 * \\
(0.010)\end{array}$ & $\begin{array}{c}0.130^{*} \\
(0.008)\end{array}$ & $\begin{array}{c}0.090^{*} \\
(0.012)\end{array}$ & $\begin{array}{l}\cdots \\
\ldots\end{array}$ & $\begin{array}{l}\ldots \\
\ldots\end{array}$ & $\begin{array}{l}\ldots \\
\ldots\end{array}$ \\
\hline Small private firms & $\begin{array}{l}\cdots \\
\cdots\end{array}$ & $\begin{array}{l}\cdots \\
\cdots\end{array}$ & $\begin{array}{l}\cdots \\
\cdots\end{array}$ & $\begin{array}{l}\cdots \\
\cdots\end{array}$ & $\begin{array}{l}\cdots \\
\cdots\end{array}$ & $\begin{array}{l}\cdots \\
\cdots\end{array}$ & $\begin{array}{c}-0.087 * \\
(0.006)\end{array}$ & $\begin{array}{c}-0.110 * \\
(0.005)\end{array}$ & $\begin{array}{l}-0.102 * \\
(0.005)\end{array}$ \\
\hline Large private firms & $\begin{array}{l}\ldots . \\
\ldots .\end{array}$ & $\begin{array}{l}\ldots \\
\ldots\end{array}$ & $\begin{array}{l}\ldots \\
\ldots\end{array}$ & $\begin{array}{l}\ldots . \\
\ldots .\end{array}$ & $\begin{array}{l}\cdots \\
\ldots\end{array}$ & $\begin{array}{l}\ldots \\
\ldots\end{array}$ & $\begin{array}{c}0.180^{*} \\
(0.021)\end{array}$ & $\begin{array}{c}0.189^{*} \\
(0.021)\end{array}$ & $\begin{array}{r}0.183^{*} \\
(0.018)\end{array}$ \\
\hline $\begin{array}{l}\text { Large mixed-ownership } \\
\text { firms }\end{array}$ & $\begin{array}{l}\cdots \\
\cdots\end{array}$ & $\begin{array}{l}\cdots \\
\ldots\end{array}$ & $\begin{array}{l}\cdots \\
\ldots\end{array}$ & $\begin{array}{l}\cdots \\
\cdots\end{array}$ & $\begin{array}{l}\cdots \\
\cdots\end{array}$ & $\begin{array}{l}\cdots \\
\ldots\end{array}$ & $\begin{array}{r}0.075^{*} \\
(0.022)\end{array}$ & $\begin{array}{r}0.087^{*} \\
(0.023)\end{array}$ & $\begin{array}{r}0.106^{*} \\
(0.025)\end{array}$ \\
\hline Adjusted Rsquared & 0.301 & 0.272 & 0.235 & 0.220 & 0.264 & 0.242 & 0.320 & 0.326 & 0.347 \\
\hline Number of observations & 19,666 & 21,114 & 20,787 & 20,685 & 19,025 & 7,259 & 26,095 & 26,316 & 26,165 \\
\hline
\end{tabular}

Notes: The sample includes employed workers between the ages of 18 and 60, who report labor income as their primary source of income. The dependent variable is log quarterly real labor income for 1985-92 and log monthly real log income for 1994-96. Robust standard errors are reported in parentheses. An asterisk indicates statistical significance at the 5 percent level. 
Table 9. Education Premia: Quantile Regressions

\begin{tabular}{|c|c|c|c|c|c|c|c|c|c|c|}
\hline & \multicolumn{2}{|c|}{ Quantile $=0.10$} & \multicolumn{2}{|c|}{ Quantile $=0.25$} & \multicolumn{2}{|c|}{ Quantile $=0.50$} & \multicolumn{2}{|c|}{ Quantile $=0.75$} & \multicolumn{2}{|c|}{ Quantile $=0.90$} \\
\hline & $\mathrm{COL}$ & HS & $\mathrm{COL}$ & $\mathrm{HS}$ & $\mathrm{COL}$ & HS & $\mathrm{COL}$ & HS & $\mathrm{COL}$ & HS \\
\hline 1986 & $\begin{array}{c}0.41 \\
(0.01)\end{array}$ & $\begin{array}{c}0.23 \\
(0.01)\end{array}$ & $\begin{array}{c}0.39 \\
(0.01)\end{array}$ & $\begin{array}{c}0.21 \\
(0.01)\end{array}$ & $\begin{array}{c}0.38 \\
(0.01)\end{array}$ & $\begin{array}{c}0.18 \\
(0.01)\end{array}$ & $\begin{array}{c}0.38 \\
(0.01)\end{array}$ & $\begin{array}{c}0.17 \\
(0.01)\end{array}$ & $\begin{array}{c}0.35 \\
(0.02)\end{array}$ & $\begin{array}{c}0.16 \\
(0.01)\end{array}$ \\
\hline 1988 & $\begin{array}{c}0.39 \\
(0.01)\end{array}$ & $\begin{array}{c}0.24 \\
(0.01)\end{array}$ & $\begin{array}{c}0.38 \\
(0.01)\end{array}$ & $\begin{array}{c}0.22 \\
(0.01)\end{array}$ & $\begin{array}{c}0.39 \\
(0.01)\end{array}$ & $\begin{array}{c}0.20 \\
(0.01)\end{array}$ & $\begin{array}{c}0.39 \\
(0.01)\end{array}$ & $\begin{array}{c}0.20 \\
(0.01)\end{array}$ & $\begin{array}{c}0.39 \\
(0.02)\end{array}$ & $\begin{array}{c}0.20 \\
(0.01)\end{array}$ \\
\hline 1989 & $\begin{array}{c}0.42 \\
(0.02)\end{array}$ & $\begin{array}{c}0.22 \\
(0.01)\end{array}$ & $\begin{array}{c}0.43 \\
(0.01)\end{array}$ & $\begin{array}{c}0.21 \\
(0.01)\end{array}$ & $\begin{array}{c}0.45 \\
(0.01)\end{array}$ & $\begin{array}{c}0.21 \\
(0.01)\end{array}$ & $\begin{array}{c}0.45 \\
(0.02)\end{array}$ & $\begin{array}{c}0.20 \\
(0.01)\end{array}$ & $\begin{array}{c}0.43 \\
(0.02)\end{array}$ & $\begin{array}{c}0.22 \\
(0.02)\end{array}$ \\
\hline 1990 & $\begin{array}{c}0.49 \\
(0.02)\end{array}$ & $\begin{array}{c}0.26 \\
(0.01)\end{array}$ & $\begin{array}{c}0.50 \\
(0.01)\end{array}$ & $\begin{array}{c}0.25 \\
(0.01)\end{array}$ & $\begin{array}{c}0.51 \\
(0.02)\end{array}$ & $\begin{array}{c}0.23 \\
(0.01)\end{array}$ & $\begin{array}{c}0.53 \\
(0.02)\end{array}$ & $\begin{array}{c}0.23 \\
(0.01)\end{array}$ & $\begin{array}{c}0.53 \\
(0.02)\end{array}$ & $\begin{array}{c}0.24 \\
(0.01)\end{array}$ \\
\hline 1991 & $\begin{array}{c}0.53 \\
(0.02)\end{array}$ & $\begin{array}{c}0.26 \\
(0.01)\end{array}$ & $\begin{array}{c}0.53 \\
(0.01)\end{array}$ & $\begin{array}{c}0.26 \\
(0.01)\end{array}$ & $\begin{array}{c}0.56 \\
(0.02)\end{array}$ & $\begin{array}{c}0.28 \\
(0.01)\end{array}$ & $\begin{array}{c}0.59 \\
(0.02)\end{array}$ & $\begin{array}{c}0.29 \\
(0.01)\end{array}$ & $\begin{array}{c}0.62 \\
(0.02)\end{array}$ & $\begin{array}{c}0.33 \\
(0.01)\end{array}$ \\
\hline 1992 & $\begin{array}{c}0.50 \\
(0.03)\end{array}$ & $\begin{array}{c}0.24 \\
(0.03)\end{array}$ & $\begin{array}{c}0.51 \\
(0.02)\end{array}$ & $\begin{array}{c}0.25 \\
(0.01)\end{array}$ & $\begin{array}{c}0.52 \\
(0.03)\end{array}$ & $\begin{array}{c}0.26 \\
(0.02)\end{array}$ & $\begin{array}{c}0.59 \\
(0.03)\end{array}$ & $\begin{array}{c}0.30 \\
(0.02)\end{array}$ & $\begin{array}{c}0.58 \\
(0.03)\end{array}$ & $\begin{array}{c}0.31 \\
(0.03)\end{array}$ \\
\hline 1994 & $\begin{array}{c}0.61 \\
(0.01)\end{array}$ & $\begin{array}{c}0.33 \\
(0.01)\end{array}$ & $\begin{array}{c}0.60 \\
(0.01)\end{array}$ & $\begin{array}{c}0.32 \\
(0.01)\end{array}$ & $\begin{array}{c}0.63 \\
(0.01)\end{array}$ & $\begin{array}{c}0.32 \\
(0.01)\end{array}$ & $\begin{array}{c}0.69 \\
(0.02)\end{array}$ & $\begin{array}{c}0.33 \\
(0.01)\end{array}$ & $\begin{array}{c}0.75 \\
(0.02)\end{array}$ & $\begin{array}{c}0.36 \\
(0.01)\end{array}$ \\
\hline 1995 & $\begin{array}{c}0.62 \\
(0.02)\end{array}$ & $\begin{array}{c}0.34 \\
(0.02)\end{array}$ & $\begin{array}{c}0.61 \\
(0.01)\end{array}$ & $\begin{array}{c}0.33 \\
(0.01)\end{array}$ & $\begin{array}{c}0.65 \\
(0.01)\end{array}$ & $\begin{array}{c}0.33 \\
(0.01)\end{array}$ & $\begin{array}{c}0.69 \\
(0.01)\end{array}$ & $\begin{array}{c}0.33 \\
(0.01)\end{array}$ & $\begin{array}{c}0.73 \\
(0.02)\end{array}$ & $\begin{array}{c}0.34 \\
(0.01)\end{array}$ \\
\hline 1996 & $\begin{array}{c}0.69 \\
(0.01)\end{array}$ & $\begin{array}{c}0.39 \\
(0.01)\end{array}$ & $\begin{array}{c}0.65 \\
(0.01)\end{array}$ & $\begin{array}{c}0.36 \\
(0.01)\end{array}$ & $\begin{array}{c}0.67 \\
(0.01)\end{array}$ & $\begin{array}{c}0.36 \\
(0.01)\end{array}$ & $\begin{array}{c}0.75 \\
(0.02)\end{array}$ & $\begin{array}{c}0.37 \\
(0.01)\end{array}$ & $\begin{array}{c}0.79 \\
(0.02)\end{array}$ & $\begin{array}{c}0.37 \\
(0.02)\end{array}$ \\
\hline
\end{tabular}

Notes: COL--college degree; HS--high school degree. The full set of regressors included four education dummies, experience and its square, and dummies for gender, urban residence and employment in the private sector. The dependent variable is log real quarterly (monthly for 1994-96) labor income.

The excluded education dummy is for primary school degree. Hence, the coefficients reported above are interpretable as the income premia, in percent (multiply by 100), for workers with a college or high school degree, respectively, relative to workers who have only a primary school degree. Bootstapped robust standard errors are reported in parentheses below the coefficient estimates. 
Table 10. Returns to Experience: Quantile Regressions

\begin{tabular}{|c|c|c|c|c|c|c|c|c|c|c|c|c|c|c|c|}
\hline \multirow{2}{*}{$\begin{array}{l}\text { Experience } \\
\text { (in years): } \\
\text { Quantile } \\
\text { point: }\end{array}$} & \multicolumn{5}{|c|}{5 years } & \multicolumn{5}{|c|}{15 years } & \multicolumn{5}{|c|}{25 years } \\
\hline & 0.10 & 0.25 & 0.50 & 0.75 & 0.90 & 0.10 & 0.25 & 0.50 & 0.75 & 0.90 & 0.10 & 0.25 & 0.50 & 0.75 & 0.90 \\
\hline 1986 & $\begin{array}{c}2.79 \\
(0.10)\end{array}$ & $\begin{array}{c}2.86 \\
(0.05)\end{array}$ & $\begin{array}{c}2.92 \\
(0.09)\end{array}$ & $\begin{array}{c}3.03 \\
(0.11)\end{array}$ & $\begin{array}{c}3.01 \\
(0.15)\end{array}$ & $\begin{array}{c}1.67 \\
(0.04)\end{array}$ & $\begin{array}{c}1.68 \\
(0.03)\end{array}$ & $\begin{array}{c}1.67 \\
(0.04)\end{array}$ & $\begin{array}{c}1.71 \\
(0.06)\end{array}$ & $\begin{array}{c}1.70 \\
(0.08)\end{array}$ & $\begin{array}{c}0.55 \\
(0.05)\end{array}$ & $\begin{array}{c}0.50 \\
(0.02)\end{array}$ & $\begin{array}{c}0.42 \\
(0.02)\end{array}$ & $\begin{array}{c}0.39 \\
(0.04)\end{array}$ & $\begin{array}{c}0.39 \\
(0.07)\end{array}$ \\
\hline 1988 & $\begin{array}{c}2.40 \\
(0.11)\end{array}$ & $\begin{array}{c}2.45 \\
(0.09)\end{array}$ & $\begin{array}{c}2.58 \\
(0.08)\end{array}$ & $\begin{array}{c}2.76 \\
(0.07)\end{array}$ & $\begin{array}{c}2.77 \\
(0.20)\end{array}$ & $\begin{array}{c}1.45 \\
(0.06)\end{array}$ & $\begin{array}{c}1.45 \\
(0.05)\end{array}$ & $\begin{array}{c}1.52 \\
(0.04)\end{array}$ & $\begin{array}{c}1.59 \\
(0.04)\end{array}$ & $\begin{array}{c}1.56 \\
(0.11)\end{array}$ & $\begin{array}{c}0.49 \\
(0.03)\end{array}$ & $\begin{array}{c}0.46 \\
(0.03)\end{array}$ & $\begin{array}{c}0.46 \\
(0.03)\end{array}$ & $\begin{array}{c}0.41 \\
(0.03)\end{array}$ & $\begin{array}{c}0.34 \\
(0.04)\end{array}$ \\
\hline 1989 & $\begin{array}{c}2.93 \\
(0.12)\end{array}$ & $\begin{array}{c}2.83 \\
(0.06)\end{array}$ & $\begin{array}{c}2.91 \\
(0.07)\end{array}$ & $\begin{array}{c}3.02 \\
(0.13)\end{array}$ & $\begin{array}{c}3.07 \\
(0.14)\end{array}$ & $\begin{array}{c}1.66 \\
(0.07)\end{array}$ & $\begin{array}{c}1.60 \\
(0.03)\end{array}$ & $\begin{array}{c}1.64 \\
(0.04)\end{array}$ & $\begin{array}{c}1.68 \\
(0.07)\end{array}$ & $\begin{array}{c}1.68 \\
(0.07)\end{array}$ & $\begin{array}{c}0.39 \\
(0.05)\end{array}$ & $\begin{array}{c}0.37 \\
(0.05)\end{array}$ & $\begin{array}{c}0.37 \\
(0.03)\end{array}$ & $\begin{array}{c}0.35 \\
(0.05)\end{array}$ & $\begin{array}{c}0.29 \\
(0.07)\end{array}$ \\
\hline 1990 & $\begin{array}{c}2.55 \\
(0.15)\end{array}$ & $\begin{array}{c}2.49 \\
(0.11)\end{array}$ & $\begin{array}{c}2.36 \\
(0.08)\end{array}$ & $\begin{array}{c}2.51 \\
(0.12)\end{array}$ & $\begin{array}{c}2.37 \\
(0.15)\end{array}$ & $\begin{array}{c}1.47 \\
(0.08)\end{array}$ & $\begin{array}{c}1.45 \\
(0.06)\end{array}$ & $\begin{array}{c}1.38 \\
(0.05)\end{array}$ & $\begin{array}{c}1.42 \\
(0.06)\end{array}$ & $\begin{array}{c}1.35 \\
(0.08)\end{array}$ & $\begin{array}{c}0.40 \\
(0.05)\end{array}$ & $\begin{array}{c}0.40 \\
(0.04)\end{array}$ & $\begin{array}{c}0.39 \\
(0.03)\end{array}$ & $\begin{array}{c}0.37 \\
(0.04)\end{array}$ & $\begin{array}{c}0.33 \\
(0.06)\end{array}$ \\
\hline 1991 & $\begin{array}{c}2.35 \\
(0.13)\end{array}$ & $\begin{array}{c}2.37 \\
(0.11)\end{array}$ & $\begin{array}{c}2.37 \\
(0.13)\end{array}$ & $\begin{array}{c}2.50 \\
(0.11)\end{array}$ & $\begin{array}{c}2.72 \\
(0.18)\end{array}$ & $\begin{array}{c}1.41 \\
(0.07)\end{array}$ & $\begin{array}{c}1.43 \\
(0.06)\end{array}$ & $\begin{array}{c}1.45 \\
(0.06)\end{array}$ & $\begin{array}{c}1.52 \\
(0.06)\end{array}$ & $\begin{array}{c}1.61 \\
(0.09)\end{array}$ & $\begin{array}{c}0.48 \\
(0.04)\end{array}$ & $\begin{array}{c}0.49 \\
(0.04)\end{array}$ & $\begin{array}{c}0.54 \\
(0.05)\end{array}$ & $\begin{array}{c}0.53 \\
(0.04)\end{array}$ & $\begin{array}{c}0.49 \\
(0.05)\end{array}$ \\
\hline 1992 & $\begin{array}{c}2.19 \\
(0.27)\end{array}$ & $\begin{array}{c}2.23 \\
(0.11)\end{array}$ & $\begin{array}{c}2.47 \\
(0.14)\end{array}$ & $\begin{array}{c}2.42 \\
(0.23)\end{array}$ & $\begin{array}{c}2.62 \\
(0.31)\end{array}$ & $\begin{array}{c}1.40 \\
(0.13)\end{array}$ & $\begin{array}{c}1.39 \\
(0.06)\end{array}$ & $\begin{array}{c}1.50 \\
(0.08)\end{array}$ & $\begin{array}{c}1.50 \\
(0.12)\end{array}$ & $\begin{array}{c}1.54 \\
(0.17)\end{array}$ & $\begin{array}{c}0.62 \\
(0.10)\end{array}$ & $\begin{array}{c}0.54 \\
(0.08)\end{array}$ & $\begin{array}{c}0.52 \\
(0.08)\end{array}$ & $\begin{array}{c}0.58 \\
(0.08)\end{array}$ & $\begin{array}{c}0.47 \\
(0.08)\end{array}$ \\
\hline 1994 & $\begin{array}{c}2.31 \\
(0.09)\end{array}$ & $\begin{array}{c}2.26 \\
(0.09)\end{array}$ & $\begin{array}{c}2.44 \\
(0.11)\end{array}$ & $\begin{array}{c}2.56 \\
(0.10)\end{array}$ & $\begin{array}{c}2.64 \\
(0.17)\end{array}$ & $\begin{array}{c}1.41 \\
(0.04)\end{array}$ & $\begin{array}{c}1.37 \\
(0.04)\end{array}$ & $\begin{array}{c}1.44 \\
(0.05)\end{array}$ & $\begin{array}{c}1.45 \\
(0.05)\end{array}$ & $\begin{array}{c}1.46 \\
(0.09)\end{array}$ & $\begin{array}{c}0.51 \\
(0.05)\end{array}$ & $\begin{array}{c}0.47 \\
(0.05)\end{array}$ & $\begin{array}{c}0.43 \\
(0.03)\end{array}$ & $\begin{array}{c}0.34 \\
(0.04)\end{array}$ & $\begin{array}{c}0.28 \\
(0.10)\end{array}$ \\
\hline 1995 & $\begin{array}{c}2.06 \\
(0.08)\end{array}$ & $\begin{array}{c}2.17 \\
(0.10)\end{array}$ & $\begin{array}{c}2.47 \\
(0.08)\end{array}$ & $\begin{array}{c}2.84 \\
(0.13)\end{array}$ & $\begin{array}{c}3.17 \\
(0.12)\end{array}$ & $\begin{array}{c}1.31 \\
(0.04)\end{array}$ & $\begin{array}{c}1.34 \\
(0.05)\end{array}$ & $\begin{array}{c}1.48 \\
(0.04)\end{array}$ & $\begin{array}{c}1.64 \\
(0.06)\end{array}$ & $\begin{array}{c}1.73 \\
(0.06)\end{array}$ & $\begin{array}{c}0.55 \\
(0.05)\end{array}$ & $\begin{array}{c}0.50 \\
(0.03)\end{array}$ & $\begin{array}{c}0.49 \\
(0.03)\end{array}$ & $\begin{array}{c}0.44 \\
(0.05)\end{array}$ & $\begin{array}{c}0.29 \\
(0.06)\end{array}$ \\
\hline 1996 & $\begin{array}{c}2.18 \\
(0.10)\end{array}$ & $\begin{array}{c}2.25 \\
(0.06)\end{array}$ & $\begin{array}{c}2.49 \\
(0.09)\end{array}$ & $\begin{array}{c}2.73 \\
(0.11)\end{array}$ & $\begin{array}{c}2.96 \\
(0.16)\end{array}$ & $\begin{array}{c}1.39 \\
(0.04)\end{array}$ & $\begin{array}{c}1.39 \\
(0.03)\end{array}$ & $\begin{array}{c}1.50 \\
(0.05)\end{array}$ & $\begin{array}{c}1.58 \\
(0.05)\end{array}$ & $\begin{array}{c}1.69 \\
(0.07)\end{array}$ & $\begin{array}{c}0.59 \\
(0.05)\end{array}$ & $\begin{array}{c}0.54 \\
(0.02)\end{array}$ & $\begin{array}{c}0.51 \\
(0.04)\end{array}$ & $\begin{array}{c}0.43 \\
(0.04)\end{array}$ & $\begin{array}{c}0.41 \\
(0.05)\end{array}$ \\
\hline
\end{tabular}

Notes: The numbers reported above are derivatives of log real quarterly (monthly for 1994-96) labor income with respect to the experience level of the worker, evaluated at the indicated experience levels. The results are expressed in percentage terms. Standard errors for these derivatives, based on bootstrapped robust standard errors for the regression coefficients, are reported in parentheses. The full set of regressors included four education dummies, experience and its square, and dummies for gender, urban residence and employment in the private sector. 
Table A1. Gini Coefficients and Variance

\begin{tabular}{|c|c|c|c|c|c|c|}
\hline & \multicolumn{3}{|c|}{ All Workers } & \multirow[b]{2}{*}{ Public Sector } & \multicolumn{2}{|c|}{ Variance } \\
\hline & All Workers & Wage Residuals & Private Sector & & Log Wage & Wage Residuals \\
\hline 1985 & 0.216 & 0.181 & 0.216 & 0.215 & 0.142 & 0.100 \\
\hline 1986 & 0.220 & 0.185 & 0.219 & 0.220 & 0.149 & 0.104 \\
\hline 1987 & 0.218 & 0.182 & 0.222 & 0.218 & 0.147 & 0.101 \\
\hline 1988 & 0.221 & 0.188 & 0.227 & 0.220 & 0.148 & 0.107 \\
\hline 1989 & 0.231 & 0.202 & 0.239 & 0.229 & 0.166 & 0.127 \\
\hline 1990 & 0.228 & 0.200 & 0.243 & 0.225 & 0.164 & 0.128 \\
\hline 1991 & 0.229 & 0.194 & 0.249 & 0.223 & 0.160 & 0.118 \\
\hline 1992 & 0.239 & 0.207 & 0.247 & 0.236 & 0.174 & 0.132 \\
\hline 1994 & 0.259 & 0.214 & 0.282 & 0.247 & 0.211 & 0.149 \\
\hline 1995 & 0.262 & 0.217 & 0.278 & 0.250 & 0.216 & 0.153 \\
\hline \multirow[t]{2}{*}{1996} & 0.261 & 0.214 & 0.284 & 0.243 & 0.218 & 0.149 \\
\hline & Men & Women & College Degree & High School & $\begin{array}{c}\text { Vocational } \\
\text { Training }\end{array}$ & $\begin{array}{c}\text { Primary } \\
\text { School }\end{array}$ \\
\hline 1985 & 0.206 & 0.185 & 0.191 & 0.203 & 0.223 & 0.212 \\
\hline 1986 & 0.209 & 0.190 & 0.195 & 0.205 & 0.229 & 0.215 \\
\hline 1987 & 0.206 & 0.188 & 0.192 & 0.207 & 0.225 & 0.209 \\
\hline 1988 & 0.213 & 0.193 & 0.211 & 0.208 & 0.225 & 0.207 \\
\hline 1989 & 0.222 & 0.216 & 0.206 & 0.219 & 0.234 & 0.219 \\
\hline 1990 & 0.222 & 0.217 & 0.206 & 0.212 & 0.227 & 0.210 \\
\hline 1991 & 0.227 & 0.213 & 0.209 & 0.212 & 0.224 & 0.203 \\
\hline 1992 & 0.235 & 0.224 & 0.219 & 0.226 & 0.236 & 0.209 \\
\hline 1994 & 0.261 & 0.235 & 0.259 & 0.238 & 0.245 & 0.214 \\
\hline 1995 & 0.261 & 0.241 & 0.256 & 0.242 & 0.245 & 0.233 \\
\hline 1996 & 0.261 & 0.242 & 0.254 & 0.239 & 0.241 & 0.234 \\
\hline
\end{tabular}

Notes: Gini coefficients are for real income (levels, not logarithms). Wage residuals are from annual OLS regressions of log earnings on a constant, four education dummies, experience and its square, and dummies for gender, urban residence, and employment in the private sector. 

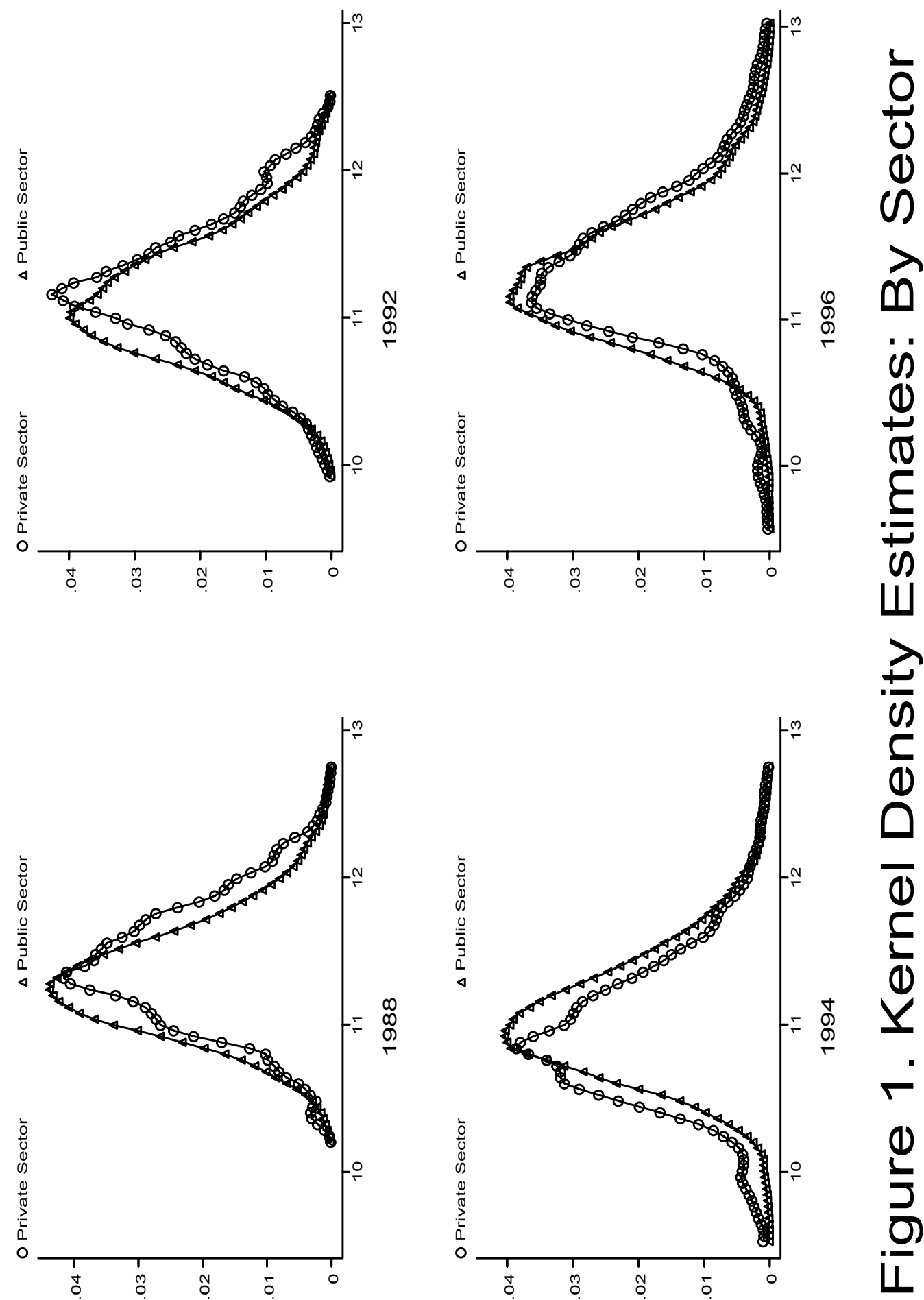


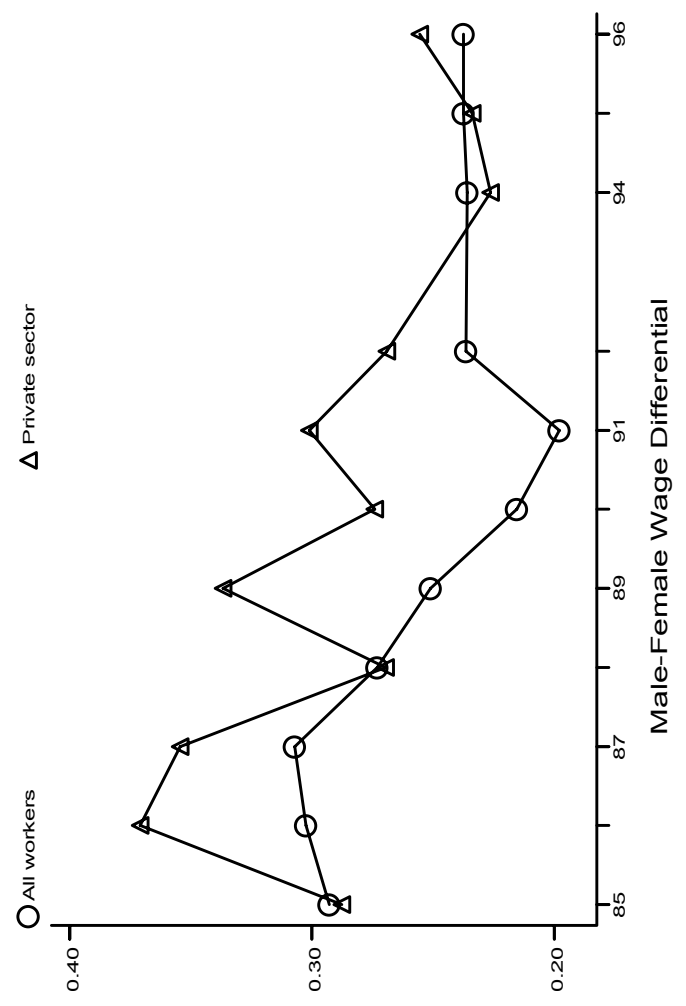

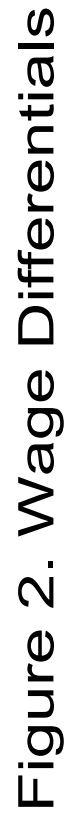

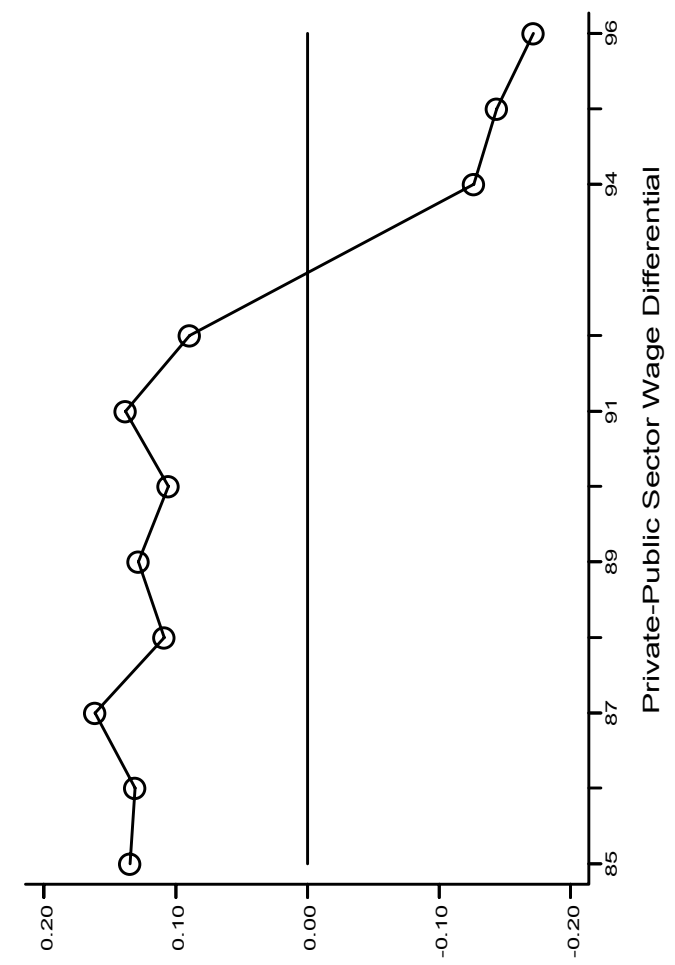


Figure 3. Kernel Density Estimates, 1988 vs. 1996
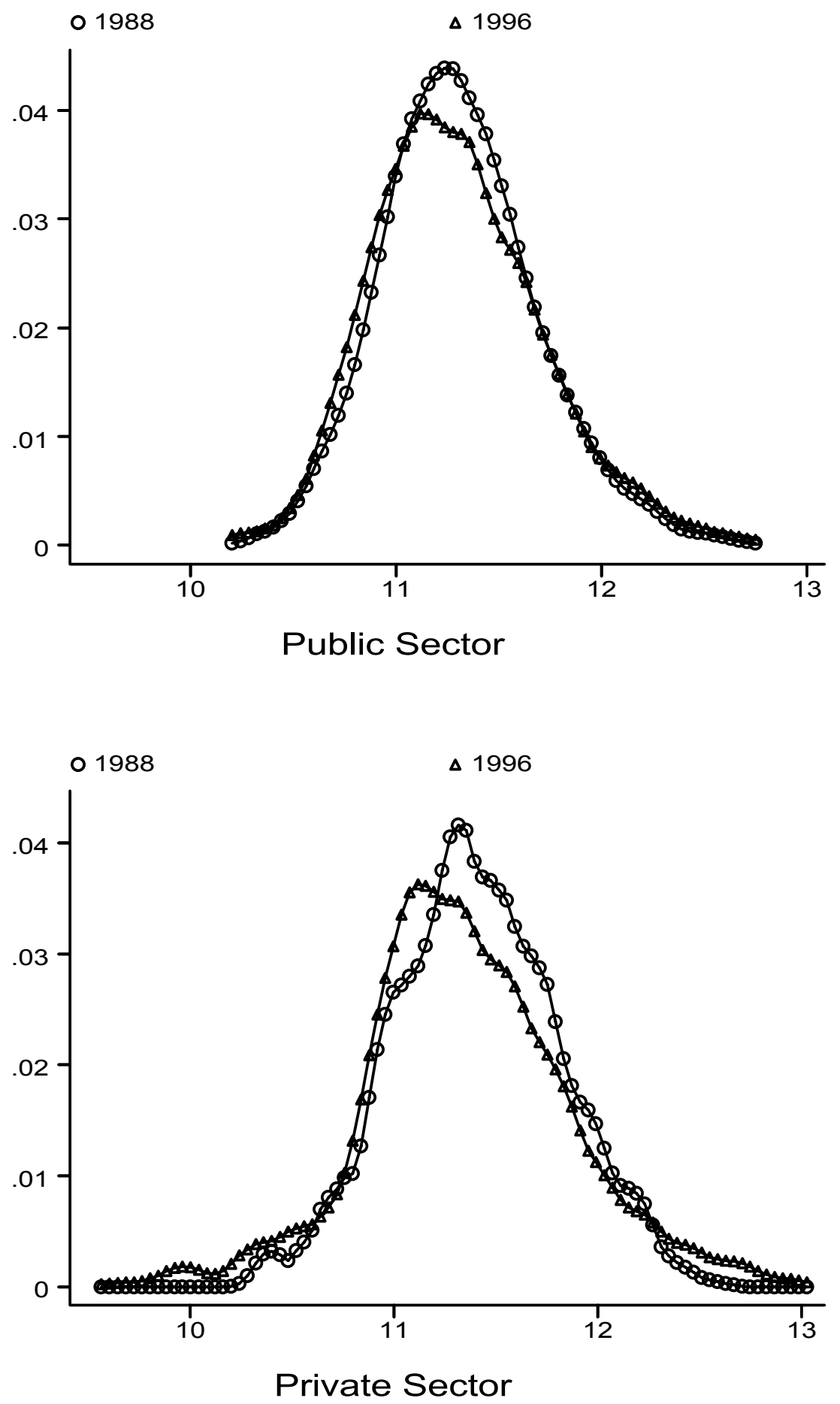

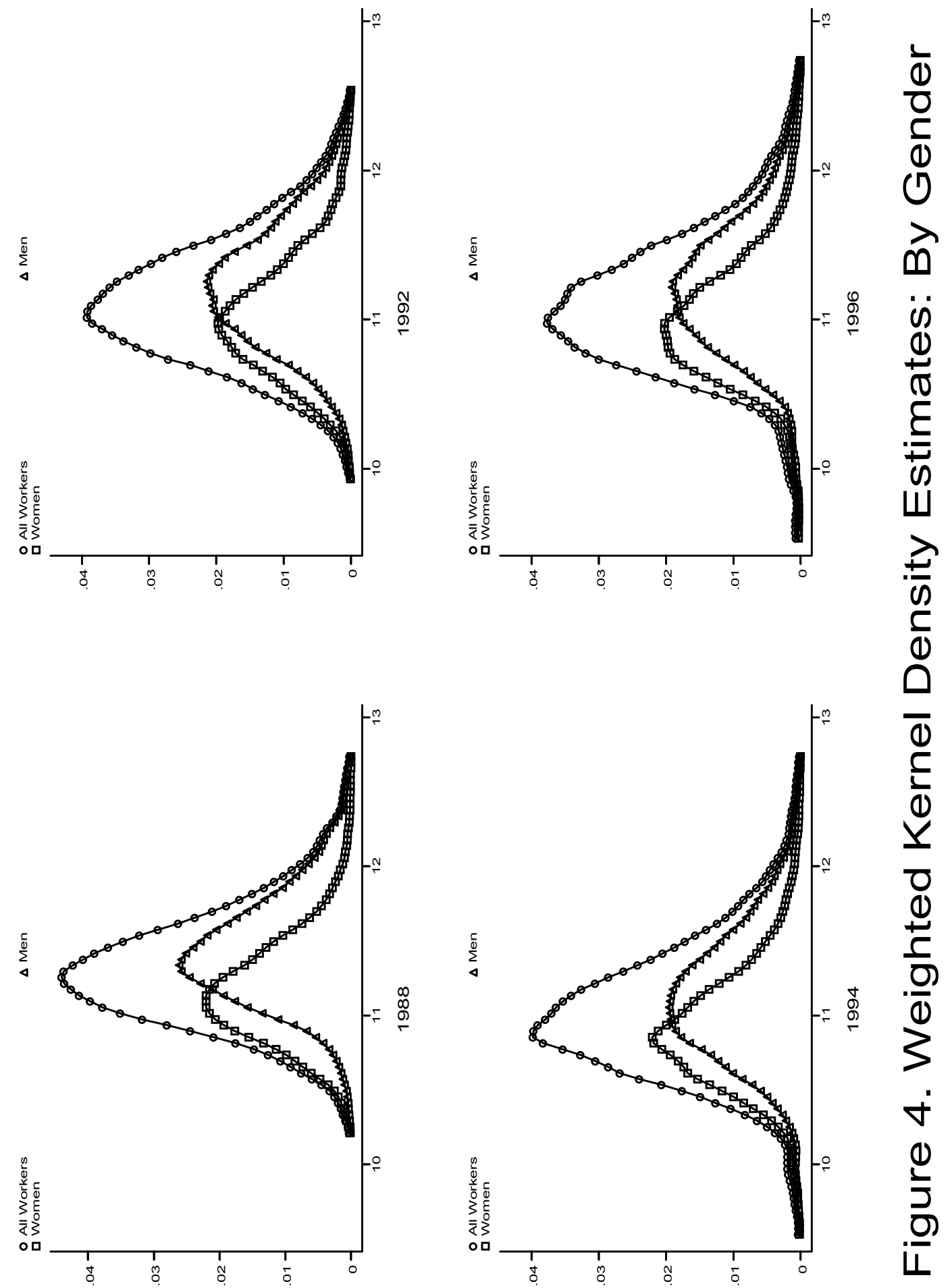

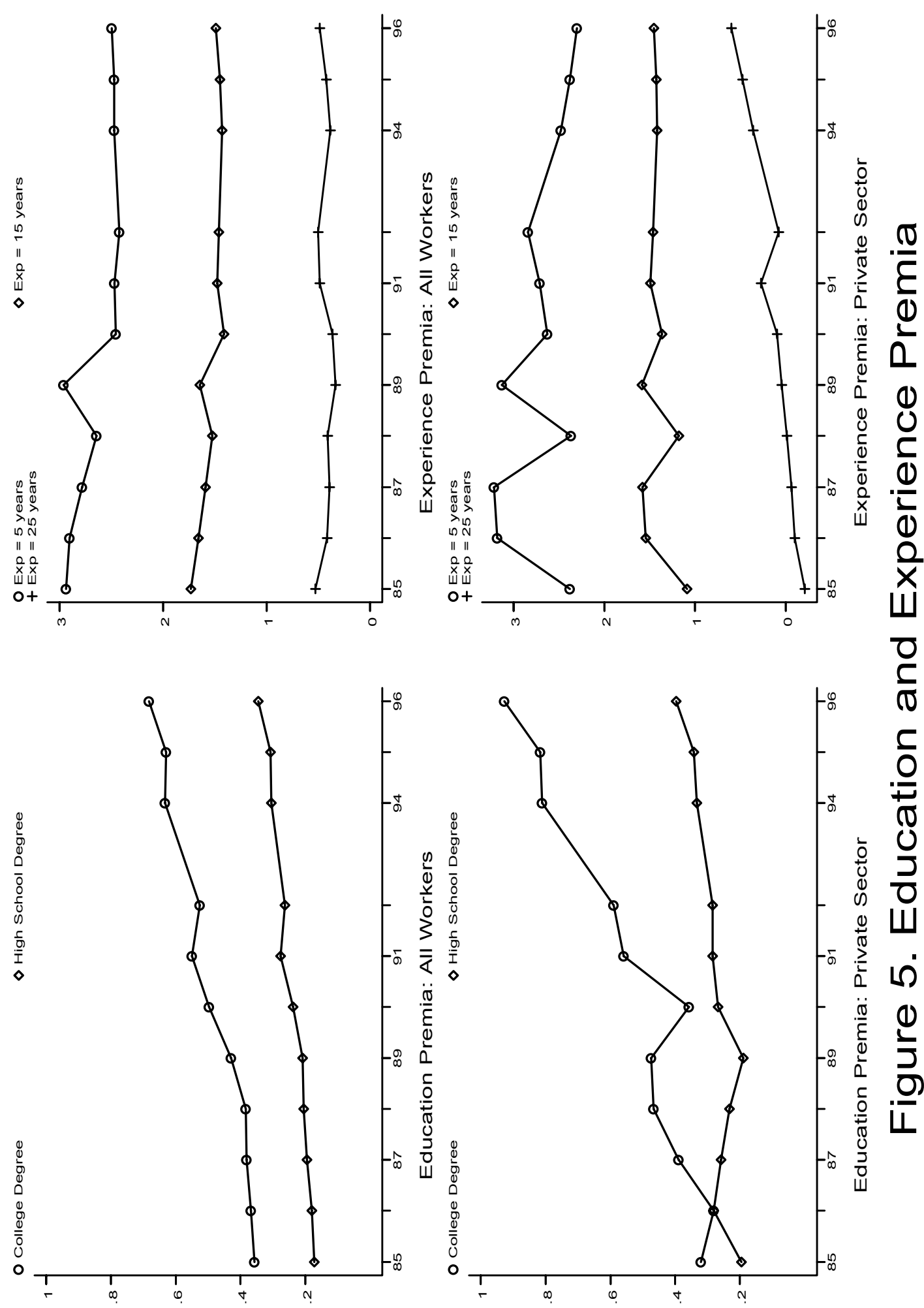


\section{IZA Discussion Papers}

$\begin{array}{ll}\text { No. } & \text { Author(s) } \\ 479 & \begin{array}{l}\text { J. T. Addison } \\ \text { C. R. Belfield }\end{array} \\ 480 & \text { G. Saint-Paul } \\ 481 & \text { E. Schlicht } \\ 482 & \begin{array}{l}\text { P. Kuhn } \\ \text { C. Weinberger }\end{array} \\ 483 & \begin{array}{l}\text { H. Rapoport } \\ \text { A. Weiss }\end{array} \\ & \begin{array}{l}\text { J. H. Bishop } \\ 484\end{array} \\ 485 & \begin{array}{l}\text { L. Woessmann } \\ \text { L. Woessmann }\end{array} \\ & \text { M. R. West }\end{array}$
A. L. Booth M. L. Bryan
R. L. Lumsdaine E. S. Prasad
A. Ciccone
G. Peri
D. Del Boca
S. Pasqua

W. F. Richter

R. Rotte

C. M. Schmidt

\section{R. Lalive}

J. Zweimüller

R. M. Leontaridi

M. E. Ward

J. Wagner

R. Sternberg
J. T. Addison
L. Bellmann
C. Schnabel
J. Wagner

M. P. Keane
Title

Area

Date

Unions and Employment Growth: The One

1

04/02

Constant?

The Complexity of Economic Policy:

6

$04 / 02$

I. Restricted Local Optima in Tax Policy Design

Hiring Standards and Market Clearing

04/02

Leadership Skills and Wages

04/02

In-Group Cooperation in a Hostile Environment: An Economic Perspective on Some Aspects of Jewish Life in (Pre-Modern) Diaspora

Institutional Effects in a Simple Model of

Educational Production

Class-Size Effects in School Systems Around the World: Evidence from Between-Grade Variation in TIMSS

Who pays for General Training? New Evidence for British Men and Women

Identifying the Common Component of International Economic Fluctuations:

A New Approach

Identifying Human Capital Externalities:

Theory with an Application to US Cities

1

Employment Patterns of Husbands and Wives

5

$04 / 02$ and Family Income Distribution in Italy (19771998)

Social Security and Taxation of Labour Subject to Subsidiarity and Freedom of Movement

2

05/02

On the Production of Victory: Empirical Deter-

minants of Battlefield Success in Modern War

Benefit Entitlement and Unemployment

Duration: The Role of Policy Endogeneity

6

05/02

Work-Related Stress, Quitting Intentions and

5

05/02

Absenteeism

The Role of the Regional Milieu for the Decision

05/02 to Start a New Firm: Empirical Evidence for Germany

German Works Councils Old and New:

3

05/02 